\title{
Conflicts Among Circuits and Transfers Within the Federal Judicial System*
}

\author{
Richard L. Marcus†
}

The weight of the Supreme Court's recent caseload has led even Justices to assert publicly that the Court cannot resolve all conflicts among the appellate courts' interpretations of federal law. ${ }^{1}$ Yet the courts of appeals, also buried under an avalanche of appeals, ever more frequently reach conflicting results. Together, these developments have spawned various proposals for resolving intercircuit conflicts-most recently the creation of a temporary Intercircuit Tribunal of the United States Courts of Appeals, ${ }^{2}$ which proponents argue will avert a breakdown in the uniformity of national law. Meanwhile, plaintiffs continue to file lawsuits asserting federal claims and the federal courts continue to decide them, often inconsistently. Not surprisingly, the existence of conflicts among the circuits gives plaintiffs a significant incentive for forum shopping.

Cases do not always remain in the forum initially selected by the plaintiff; in the federal system transfers to another court occur with increasing frequency. Since 1948, a defendant has been able to combat the inconvenience caused by plaintiff's forum shopping in the federal system by moving to transfer the action to a more convenient district under section 1404(a) of the Judicial Code. ${ }^{3}$ In addition, under the multidistrict litigation transfer statute passed in 1968,4 cases having common issues of fact may be transferred to a single district for coordinated pretrial proceedings, with later transfer for trial under section 1404(a) often a possibility. Be-

- Copyright $\odot$ 1984, Richard L. Marcus.

$\dagger$ Associate Professor of Law, University of Illinois. B.A., 1969, Pomona College; J.D., 1972, University of California, Berkeley. I am indebted to my colleague Gene Scoles for his review of a draft of this Article and his numerous helpful comments. The errors that remain are, of course, mine.

1. E.g., Burger, Annual Report on the State of the Judiciary, 69 A.B.A. J. 442, 445-46 (1983) (asserting that "clear majority" of Justices feel that "something must be done" about caseload burdens of Court); Commission on Revision of the Federal Court Appellate System, Structure and Internal Procedures: Recommendations for Change, 67 F.R.D. 195, 408 (1975) (letter from Justice Rehnquist, noting that "[c]onflicting views on questions of federal law remain unresolved") (hereinafter cited as Hruska Commission]; White, A Salute to the Circuits, 28 Loy. L. REv. 669, 670 (1982) ("[T]he courts of appeals these days are in large part-and necessarily so-finally responsible for the interpretation and enforcement, and hence for the condition, of the federal law."). For a discussion of the appellate crunch and the development of conflicts between the circuits, see infra Part III.

2. For a description of the bills now pending before Congress, see infra note $\mathbf{8 2}$.

3. 28 U.S.C. § 1404(a) (1976).

4. 28 U.S.C. $\S 1407$ (1976 \& Supp. V 1981). 
cause of the increasing availability of transfer and because of the growing number of cases, over two thousand cases are now transferred each year. ${ }^{5}$

The interaction between these two trends-toward more frequent conflicts and more numerous transfers-raises a choice-of-law question: When a federal claim is transferred, should the transferee court apply the interpretation of the circuit in which the case was filed or of the circuit to which it was transferred? Until 1964, the lower federal courts that had confronted this problem agreed that the transferee court could apply its own interpretation. ${ }^{\circ}$ Several of these courts noted that despite the divergent interpretations of federal law, it is a single body of rules applicable in all federal courts and parties are not entitled to select a preferred interpretation. In 1964, however, the Supreme Court held in Van Dusen v. Barrack $^{7}$ that the law of the state in which the transferor court sat ${ }^{8}$ would continue to apply after a section 1404(a) transfer of a diversity case to a district court sitting in another state. Since then, lower courts have generally concluded that Van Dusen also requires application of the transferor circuit's interpretation of federal law to transferred federal claims. ${ }^{\circ}$ Despite some murmuring of dissent, ${ }^{10}$ however, neither courts nor commentators have analyzed the application of Van Dusen to transferred federal claims. That is the purpose of this Article.

The Article begins by briefly describing the operation of the federal transfer statutes. It then reviews Van Dusen's resolution of the choice-oflaw problem in diversity cases and finds that the decision was based on two grounds: the principles of Erie Railroad v. Tompkins Co., ${ }^{11}$ and the presumed legislative intent behind section 1404(a) to preserve the plaintiff's "venue privilege" to shop for favorable state law. Turning to questions of federal law, the Article finds that neither the existence of conflicts among the circuits nor the perception that circuits treat certain issues dif-

5. See infra note 16 ; p. 681.

6. See infra p. 692.

7. 376 U.S. 612 (1964).

8. This does not mean that the transferor state's substantive law will necessarily govern the case following transfer. The transferee court must apply the substantive law that the transferor court would have applied following a choice-of-law determination. Because Klaxon Co. v. Stentor Elec. Mfg. Co., 313 U.S. 487 (1941), requires a district court to apply the choice-of-law rules of the state in which it sits in a diversity case, see infra p. 682, the transferor state's choice-of-law rules identify the state whose substantive law will govern the case following transfer.

9. See infra p. 693.

10. Judge Henry Friendly has asserted that "I take [Van Dusen] to be limited to choices of state law." Friendly, The "Law of the Circuit" and All That, 46 ST. JoHN's L. REv. 406, 412 (1972) (emphasis in original); see also In re Pittsburgh \& L.E.R.R. Sec. \& Antitrust Litig., 543 F.2d 1058 (3d Cir. 1976). There the court noted that others had applied Van Dusen to transfers of federal claims and observed, "It is difficult to understand why this should be so since Van Dusen v. Barrack involved conflicting state wrongful death policies, while in theory, at least, federal law, in its area of competence, is assumed to be nationally uniform, whether or not it is in fact." Id. at $1065 \mathrm{n} .19$ (emphasis in original).

11. 304 U.S. 64 (1938). 
ferently is likely to be eliminated in the near future. Accordingly, the choice-of-law problem in transferred federal claims cases will endure.

Against this background, the Article analyzes the proper handling of the choice-of-law question for transferred federal claims. It finds first that neither of Van Dusen's principles provides a sufficient reason to prefer the transferor circuit's interpretation in such cases. Erie is simply irrelevant where federal claims are involved, and its policies have no bearing on the choice between interpretations of federal law. The venue privilege is similarly inapposite once plaintiff's choice of forum has been vetoed by a transfer. The Van Dusen Court stressed the venue privilege because there is no federal principle by which to select the state law that should govern diversity cases. Where federal claims are transferred, however, the principle that the transferee federal court is competent to decide federal issues correctly indicates that the transferee's interpretation should apply. If Van Dusen compels the transferee court to decide the case in a way it views as wrong, then that court's competence is undermined. Moreover, application of the Van Dusen rule reduces the effectiveness of the transfer statutes by creating obstacles to the efficient handling of transferred federal claim cases. Van Dusen therefore should not govern such cases.

\section{Transfer in the Federal Judicial System}

Until 1948, transfer of cases among federal courts was impossible. Dismissal on grounds of forum non conveniens was the only remedy for abuse of venue provisions. In 1947 the Supreme Court confirmed the availability of such dismissal as a matter of federal common law where trial in the forum chosen by plaintiff would unreasonably burden defendant or the court. ${ }^{22}$ Because it relies on dismissal, however, forum non conveniens is tailored for situations in which the more convenient forum is in a different judicial system.

In 1948, Congress provided section 1404(a) as an alternative to dismissal for cases where the more convenient forum is another federal court. Section 1404(a) authorizes the federal judge before whom a civil action is pending to transfer it "[ $\mathrm{f}]$ or the convenience of the parties and witnesses, in the interest of justice," albeit only to a district where venue and jurisdiction are proper. ${ }^{13}$ On motions made under section 1404(a), the plain-

12. Gulf Oil Corp. v. Gilbert, 330 U.S. 501, 511-12 (1947). For a discussion of the common law doctrine of forum non conveniens, see Blair, The Doctrine of Forum Non Conveniens in AngloAmerican Law, 29 Colum. L. Rev. 1 (1929).

13. 28 U.S.C. $\$ 1404$ (a) (1976). In Hoffman v. Blaski, 363 U.S. 335 (1960), the Supreme Court construed the statute to forbid transfer to a district where venue would not have been proper even though defendants moved to transfer and therefore were clearly willing to waive any objections to venue. 
tiff's choice of venue is generally accorded substantial weight and the moving party must make a showing of inconvenience sufficient to overcome it. ${ }^{14}$ But that showing need not be sufficient to justify dismissal. ${ }^{15}$ After transfer, the transferee district court has full responsibility for disposition of the case, and appeal from its judgment is to the transferee circuit's court of appeals. Recently, about 2,000 cases per year have been transferred under section 1404(a)..$^{10}$

In 1968, Congress added a major transfer provision, the Multidistrict Litigation Act. ${ }^{17}$ This statute, based on the experiences of the federal courts with voluntary pretrial coordination of thousands of electrical equipment price-fixing antitrust cases, ${ }^{18}$ authorized transfer of cases having a common question of fact to a single district for coordinated or consolidated pretrial procedures. Transfers under the newer statute are made not by a single judge, as is true under section 1404(a), but rather by the Judicial Panel on Multidistrict Litigation. ${ }^{19}$ The statute provides that transfers should depend on the convenience of the witnesses and parties and on judicial efficiency. But as a practical matter the Panel gives considerations of judicial economy primary importance; the interests of the parties thus receive correspondingly less emphasis. ${ }^{20}$ Cases may be trans-

14. See 15 C. Wright, A. Miller \& E. Cooper, Federal. Practice \& Procedure $\$ 3848$

(1976) [hereinafter cited as Federal Practice \& Procedure].

15. Norwood v. Kirkpatrick, 349 U.S. 29, 30-32 (1955).

16. There are no published figures regarding transfers pursuant to $\S 1404(\mathrm{a})$. However, the Administrative Office of the United States Courts has maintained records on the number of such transfers since fiscal year 1975. They are as follows:

Fiscal year ending 6/30/75 - 1,836 cases transferred.

Fiscal year ending $6 / 30 / 76-2,016$ cases transferred.

Fiscal year ending $6 / 30 / 77-1,712$ cases transferred.

Fiscal year ending $6 / 30 / 78-1,909$ cases transferred.

Fiscal year ending $6 / 30 / 79-1,763$ cases transferred.

Fiscal year ending $6 / 30 / 80-2,120$ cases transferred.

Fiscal year ending $6 / 30 / 81-2,435$ cases transferred.

Fiscal year ending $6 / 30 / 82-2,445$ cases transferred.

Letter from Richard L. Marcus to James A. McCafferty, Chief of Statistical Analysis \& Reports Division, Administrative Office of the United States Courts (July 1, 1983) (on file with author); letter from James A. McCafferty to Richard L. Marcus (July 7, 1983) (on file with author).

17. 28 U.S.C. § 1407 (1976 \& Supp. V 1981).

18. Note, The Judicial Panel and the Conduct of Multidistrict Litigation, 87 Harv. L. Rev. 1001, 1001 \& n.1 (1974).

19. 28 U.S.C. $§ 1407$ (d) (1976).

20. Specific cases cannot easily be cited to prove this point, but it is evident from a review of the Panel's decisions in toto and is confirmed by commentators. See, e.g., Herndon, Section 1407 and Antitrust Multidistrict Litigation-The First Decade, 47 ANTITRust L.J. 1161, 1169 (1979) ("The Panel's decisions have virtually eliminated the requirement that transfer "will be for the convenience of parties and witnesses' as a significant factor affecting the transfer of antitrust actions."); Herndon \& Higginbotham, Complex Multidistrict Litigation-An Overview of 28 U.S.C.A. $\$ 1407,31$ BAYLoR L. REv. 33, 43-45 (1979) ("Doubt is generally resolved in favor of transfer . . .."); Levy, Complex Multidistrict Litigation and the Federal Courts, 40 Fordoram L. REv. 41,49 (1971) (judicial efficiency "plays the greatest role"); Note, supra note 18, at 1003 ("Once a threshold level of potential savings [in judicial time] is found, however, transfer is almost inevitable."). 
ferred to any district, whether or not jurisdiction or venue would originally have been proper there. ${ }^{21}$ Once the Panel has designated a given set of facts for multidistrict treatment, any cases filed later that involve the same fact issues are automatically transferred as "tag-along" cases to the court designated by the Multidistrict Panel unless a party files a motion to vacate the transfer order. ${ }^{22}$ During the first fourteen years of its operation, the Panel transferred an average of more than 500 cases annually; ${ }^{23}$ for the last five years it has transferred an average of 860 cases per year. ${ }^{24}$

Although the multidistrict transfer statute authorizes transfer only for pretrial purposes, and specifically provides that the cases shall be remanded to the transferor district for trial, ${ }^{25}$ only a few cases are ever remanded. ${ }^{28}$ The transferee judge has complete authority to make pretrial rulings, including an order to transfer the trial to his own district under section 1404(a). ${ }^{27}$ Not surprisingly, transferee judges immersed in complex cases often feel that a transfer under section 1404(a) would promote justice because a remand would waste their hard-earned understanding of the issues and would impose an unnecessary burden on the judge to whom the case is remanded. Even without a transfer under section 1404(a), transferee judges can often dispose of part or all of a case on summary judgment; ${ }^{28}$ one commentator has observed that "transferee courts have usually attempted to decide all substantive issues in the litigation."29

21. 28 U.S.C. § 1407 (a) (1976).

22. J.P.M.D.L.R. 9, 10. The Rules of the Panel are printed at 28 U.S.C. § 1407 (1976 \& Supp. V 1981). J.P.M.D.L.R. 1 defines a tag-along action as "a civil action involving common questions of fact with actions previously transferred." Such an action can be transferred even before all defendants are served. J.P.M.D.L.R. 10(c). Once transfer is accomplished, a party who desires a remand, absent the recommendation of the transferee judge, bears an "especially heavy burden." Weigel, The Judicial Panel on Multidistrict Litigation, Transferor Courts and Transferee Courts, 78 F.R.D. 575, 584 (1978).

23. See W. Foley, Annual Report of the Director of the Administrative Office of THE UNITED STATES CourTs 130 (1982) (reporting that between July 1968 and June 1982 the Panel had transferred 7,380 cases pursuant to $\$ 1407$ ).

24. These figures are from the Annual Report of the Director of the Administrative Office of the Uniled States Courts for the years 1978 to 1982.

25. 28 U.S.C. \$ 1407 (a) (1976).

26. See Weigel, supra note 22, at 583 (noting that less than five percent of actions transferred by Panel were in fact remanded).

27. J.P.M.D.L.R. 11(b); see Kohr v. Allegheny Airlines, 504 F.2d 400, 402 (7th Cir. 1974), cert. denied, 421 U.S. 978 (1975); Pfizer, Inc. v. Lord, 447 F.2d 122, 124-25 (2d Cir. 1971); In re Bristol Bay Salmon Fishery Antitrust Litig., 424 F. Supp. 504, 507 (J.P.M.D.L. 1976).

28. E.g., Humphreys v. Tann, 487 F.2d 666, 668 (6th Cir. 1973), cert. denied, 416 U.S. 956 (1974); Reidinger v. Trans World Airlines, 463 F.2d 1017, 1018 n.2 (6th Cir. 1972).

29. Note, The Experience of Transferee Courts Under the Multidistrict Litigation Act, $39 \mathrm{U}$. CHI. L. REv. 588, 607-08 (1972) [hereinafter cited as Note, Experience of Transferee Courts]. Arguably such dispositions on the merits by transferee judges go beyond Congress' intent, see id. at 595-96, but there has been no effort to prevent them. On the contrary, there have been suggestions that Congress should authorize transfer for trial. The Antitrust Section of the American Bar Association has proposed to extend multidistrict transfer to include transfer for trial, but only after transfer to a proper 
Moreover, if the case is later remanded to the transferor court, that court is arguably bound by such rulings. ${ }^{30}$ If final judgment is entered by the transferee judge, however, appeal is to the court of appeals of the transferee circuit. Thus, the transferee court usually decides the merits of the case under either section 1404(a) or the Multidistrict Litigation Act.

\section{Transfer and Choice of Law in Diversity Cases}

Under Klaxon Co. v. Stentor Electric Manufacturing Co., ${ }^{\mathbf{3 1}}$ federal courts must apply the choice-of-law rules of the states in which they sit to issues of state law arising in diversity cases. Despite Klaxon, a federal court could indirectly affect the choice of law by dismissing on grounds of forum non conveniens, since dismissal would compel the plaintiff to refile in another state, whose choice-of-law rules would subsequently apply. Dismissal is the only situation, however, in which a federal court has an independent role to play in deciding which state's law will apply to a claim based on state law.

Transfer within the federal system greatly complicates the application of Klaxon. Almost from the beginning, section 1404(a) created a new species of choice-of-law problem in diversity cases: Should the transferee court apply the choice-of-law rules of the state in which it sits or the state in which the transferor court sits? In 1950, the Tenth Circuit opted for the law of the transferor state in Headrick v. Atchison, Topeka \& Santa Fe Railway. ${ }^{32}$ Plaintiff there, a Missouri resident, alleged that he had been injured in California while riding on a bus operated by defendant, a Kansas corporation. The statute of limitations had run in Missouri, Galifornia, and Kansas, so plaintiff sued in state court in New Mexico, which had a longer limitations period. ${ }^{33}$ Defendant removed to federal court and moved to dismiss on forum non conveniens grounds or, in the alternative, to transfer to California under section 1404(a). The district court granted the motion to dismiss, reasoning that transfer would be pointless because

venue. See ABA, Summary of Action of the House of Delegates 26-27 (1976); see also Note, Air Crash Litigation and 28 U.S.C. Section 1407: Experience Suggests A Solution, 1981 U. ILL. L. REv. 927 (favoring transfer for trial in airplane crash cases).

30. See Weigel, supra note 22 , at 577 (" $[I]$ t would be improper to permit a transferor judge to overturn orders of a transferee judge even though error in the latter might result in reversal of the final judgment of the transferor court."). Judge Weigel did not directly address the situation in which the transferor court disagrees with the ruling of the transferee court due to a conflict between the transferor and transferee circuits.

31. 313 U.S. 487 (1941). The wisdom of Klaxon has been questioned, but that dispute is beyond the scope of this Article. For a review of such issues, see R. Weintraub, Commentary on THE Conflict of LAws $\S \S 10.5,10.8$ (2d ed. 1980).

32. 182 F.2d 305 (10th Cir. 1950).

33. Plaintiff admitted that he selected New Mexico because its limitations period had not run. See id. at 311 . 
California law would apply after a transfer, and the case would then simply be dismissed as time-barred.

The Tenth Circuit reversed. It held that the passage of section 1404(a) limited the district court's power to dismiss on grounds of forum non conveniens to situations in which transfer to the more convenient forum was impossible. ${ }^{34}$ Since transfer to Galifornia was clearly possible, dismissal was forbidden. The court concluded further that transfer would not affect the law applied to the case. It explained that plaintiff had a "legal right to select any forum where the defendant was amenable to process" and that "[u]pon removal ... the case would remain a New Mexico case controlled by the law and policy of that state . . . "ss Because Erie prevents the federal court from "tak[ing] away that which a state has given," Tenth Circuit held that "no rights acquired in the forum selected by plaintiff would be lost on transfer."st

Spurred in large part by Headrick, Professor Brainerd Currie published a long article in 1955 examining the impact of the transfer provision on choice-of-law issues. ${ }^{38} \mathrm{He}$ began by arguing that every available option for handling the problem had defects. ${ }^{39}$ Emphasizing the role that forum non conveniens had played in the evolution of section 1404(a), he

34. Id. at 308. This conclusion appears to be correct. See, e.g., Norwood v. Kirkpatrick, 349 U.S. 29, 32 (1955) (dismissal "eliminated" by passage of $\S 1404(a)$ ); 1 J. MOORE, J. LuCAs, H. Frnk, D. Weckstein \& J. Wicker, Moore's Federal Practice II 0.145 [6.-1], at 1636 (2d ed. 1983) ("Where another federal district court is the more convenient forum, the power to dismiss . . . no longer exists . . . .") [hereinafter cited as MOORE's Federal. Practice]. As a consequence, even the limited power to affect choice of law by dismissing on forum non conveniens grounds, see supra $\mathrm{p}$. 682 , no longer exists.

35. 182 F.2d at 309. Under Klaxon, the reference to "law" of New Mexico refers to the choiceof-law rules of that state. In Headrick, the court of appeals did not address possible due process arguments against application of other rules of New Mexico law (i.e., statute of limitations) to the case. See infra note 149. Nevertheless, it apparently assumed that New Mexico choice-of-law rules would require application of New Mexico's longer limitations period.

36. 182 F.2d at 309.

37. Id. at 310 . It should be apparent that the Headrick court's acquired rights idea is different from the "vested rights" approach of Joseph Beale, the reporter of the First Restatement of the Law of Conflict of Laws. Beale argued that, without reference to initiation of litigation, rights were vested by conduct. See E. Scoles \& P. HAy, Confuct of LAws $\$ 2.5$ (1982). The Headrick court reasoned that the rights involved were acquired under New Mexico law because the lawsuit was filed there.

38. Currie, Change of Venue and the Conflict of Laws, 22 U. CHI. L. Rev. 405 (1955). The article is 99 pages long. It discusses Headrick, described as the leading case, at $408-15,444-45$, 470-82.

39. Currie posited three possibilities: (1) applying the law of the transferee state; (2) applying the law of the transferor state; and (3) applying the law of the transferor state unless that state would dismiss on grounds of forum non conveniens. He found the first obnoxious to Erie because the substantive law would change if the accident of diversity allowed the case into federal court. He questioned the second because cases filed in federal court would be governed by the choice-of-law rules of a state that would have dismissed the action on forum non conveniens grounds. He found the third inadequate because of the difficulty of deciding whether the state court would dismiss on forum non conveniens grounds; if so, whether it would condition that dismissal on some agreement regarding the applicable law; and whether, in the event of such dismissal, the plaintiff would refile in the state to which transfer is ordered under $\S 1404$ (a). See Currie, supra note 38, at 438-53. 
saw no reason to interpret the statute to protect the wanton forum shopping exhibited in Headrick. ${ }^{40}$ He proposed instead that the federal courts develop "enlightened principles of conflicts of law" to decide what law should apply following transfer. ${ }^{41}$ Five years later, however, he published a retraction, ${ }^{42}$ in which he explained that his earlier proposal was "fundamentally and impossibly wrong"43 because no choice-of-law system could be developed in the abstract without an examination of the interests of the various states involved. As a consequence, Currie concluded that the problem of choice of law after transfer was "insoluble . . . while diversity jurisdiction exists" 44 because "no choice-of-law rule can possibly be invented that will do anything more than subordinate the policy of one state to that of the other."

Despite Currie's pessimism, in 1964 the Supreme Court decided how federal courts should handle the choice-of-law problem in transfer of diversity cases. In Van Dusen v. Barrack, ${ }^{46}$ the Supreme Court adopted much of Headrick's reasoning to hold that the law of the transferor court should govern in such transfers. The suits in Van Dusen were brought by personal representatives of Pennsylvania residents killed when an airliner bound for Philadelphia crashed in Boston Harbor shortly after takeoff. Pursuant to section 1404(a), the district court ordered the forty actions filed in Pennsylvania transferred to Massachusetts, where over one hundred other actions were already pending. ${ }^{47}$ Plaintiffs opposed the transfer on the ground that they would be harmed by the differences between the Pennsylvania and Massachusetts measures of damages in wrongful death cases. ${ }^{48}$ Like most states, Pennsylvania allowed recovery to compensate for

40. Currie's theory was that $\S 1404$ (a) evolved from forum non conveniens even though it was different in significant respects from the common law doctrine. Accordingly, he felt that the elimination of the power to dismiss (with its concomitant power to affect which choice-of-law rules apply) implied some authority for the federal court directly to affect choice of law. Sep Currie, supra note 38, at $466-67$.

41. As posited by Currie, this system would begin with the premise that transferor law should apply, and would require the party desiring a change in law to justify it. As part of the transfer process the transferor court could, however, decide that some other law "ought" to apply. In making this determination, the court should not, he reasoned, select the law of the transferee state simply because it is the transferee. Instead, pursuant to a "federal law of conflict of laws," it should, as part of the transfer order, direct that the specified law apply after transfer. That order would thenceforth become the law of the case. Sep Currie, supra note 38, at 460-64. For a more recent argument favoring the development of federal principles of choice of law, see Abrams, Pouer, Convenience and the Elimination of Personal Jurisdiction in the Federal Courts, 58 IND. L.J. 1, 49-57 (1982). (1960).

42. Currie, Change of Venue and the Conflict of Laws: A Retraction, 27 U. CHI. L. REv. 341

43. Id. at 341 .

44. Id. at 348 .

45. Id. at 346 .

46. 376 U.S. 612 (1964).

47. Id. at 614 .

48. Plaintiffs also argued that, because they were not qualified in Massachusetts to act as representatives of the estates of the deceased, defendants could claim after transfer that plaintiffs lacked 
loss, but Massachusetts measured damages based on the culpability of the defendant's conduct and limited the award to $\$ 20,000$. .9 $^{\text {Assuming the }}$ Pennsylvania choice-of-law rules would call for application of the Pennsylvania measure of damages, but that after transfer Massachusetts choice-of-law rules would apply pursuant to Klaxon and would require reference to the Massachusetts damage measure, plaintiffs claimed that this adverse change in law should preclude transfer.

The Supreme Gourt, however, held that transfer was not precluded by differences between Pennsylvania law and Massachusetts law because "[a] change of venue under § 1404(a) generally should be, with respect to state law, but a change of courtrooms." ${ }^{\text {\$0 }}$ Accordingly, Pennsylvania choice-oflaw rules would still determine the proper measure of damages. The Court reserved the question whether the same principles would preserve transferor law if the plaintiff requested the transfer or if the state in which the case was originally filed would itself have dismissed the case on forum non conveniens grounds. ${ }^{\text {s1 }}$ With respect to defendants' motions to transfer diversity cases, however, the choice-of-law issue was settled.

The Van Dusen Court defined the issue primarily as one of statutory construction, but it relied heavily upon Headrick to support its analysis. ${ }^{52}$ First, the Court characterized section 1404(a) as a "judicial housekeeping measure" designed only to ameliorate the geographical inconvenience of trial in a distant forum. ${ }^{63}$ Given this limited purpose, the Court found that the statute "was not designed to narrow the plaintiff's venue privilege or to defeat the state-law advantages that might accrue from the exercise of this venue privilege." 34 Otherwise, it noted, defendants could turn the transfer statute itself into a device for forum shopping.

Second, the Court reasoned that its statutory interpretation was supported by the Erie policy of uniformity of law within a state, a policy which also led to Klaxon's requirement that federal courts apply the

capacity to sue. Id. at 615 . Rule 17 (b) provides that capacity of an individual acting in a representative capacity to sue "shall be determined by the law of the state in which the district court is held," FED. R. Civ. P. 17(b), which would be Massachusetts after transfer. Plaintiff's principal Rule 17(b) argument was that Massachusetts was not a district in which the action "might have been brought" within the meaning of $\S 1404(\mathrm{a})$ as interpreted in Hoffman v. Blaski, 363 U.S. 335 (1960). In Van Dusen, the Court rejected this argument, thus narrowing Hoffinan to federal venue and jurisdictional requirements. 376 U.S. at $621-24$. With respect to capacity, the Court held that Rule 17(b) would be interpreted to require application of the law of the transferor state. 376 U.S. at 641-43.

49. See 376 U.S. at 627 (acknowledging that laws of Massachusetts and Pennsylvania are "significantly different").

50. Id. at 639 (footnote omitted).

51. Id. at 640 .

52. See id. at 631-32.

53. Id. at 636-37. This construction undercuts Professor Currie's assumption that $\S 1404(a)$ and forum non conveniens are closely related. See supra note 40.

54. 376 U.S. at 635. 
choice-of-law rules of the states in which they sit. ${ }^{55}$ For purposes of this policy, the Court explained, "the critical identity to be maintained is between the federal district court which decides the case and the courts of the State in which the action was filed." versity in the Pennsylvania cases should not result in the application of another state's law.

\section{The Development of Conflicts Among the Circuits}

In an ideal system, Van Dusen problems would not arise in transfers of cases involving federal claims because all courts would interpret federal law uniformly. But the system is not ideal; historical development and current necessity make conflicts among the circuits inevitable. Before 1891 , appellate review in the federal system was basically limited to review by the Supreme Court. ${ }^{87}$ In this system there were few opportunities for conflicting interpretations of federal law, ${ }^{88}$ but the burden eventually placed on the Supreme Court's caseload necessitated changes. In 1891, after decades of debate, Congress passed the Evarts Act, ${ }^{59}$ which provided an intermediate level of appellate review by creating courts of appeals for each circuit.

Congress may never have intended that the concept of law of the circuit develop, ${ }^{60}$ but something of the sort was inevitable because the Evarts Act directed each court of appeals to interpret federal law independently. Accordingly, although courts of appeals pursue internal uniformity, ${ }^{61}$ no

\footnotetext{
55. Id. at $637-40$.

56. Id. at 639 (footnote omitted).

57. Technically, the circuit courts had jurisdiction to review decisions of the district courts in certain matters, but there was no trace of a system of intermediate appellate review between the trial courts (which included the circuit courts) and the Supreme Court. See F. FrankfurTER \& J. LANDIS, The BUSINESS OF THE SUPREME CourT 12-13 (1927). Indeed, the original circuit courts were the weak spot of the system and were repeatedly criticized until they were abolished in 1911. Act of March 3, 1911, ch. 231, 36 Stat. 1087; see P. Bator, P. Mishkin, D. Shapiro \& H. WeChsler, Hart and Wechsler's The Federal Courts and the Federal System 36-41 (2d ed. 1973).

58. While conflicting interpretations were not a great concern, the absence of effective appellate supervision created arbitrary and disparate results. The ineffectiveness of review by the circuit courts, on which the district judges themselves sat, often made it appear that district judges had untrammelled power to decide as they pleased. See F. FrankfurTer \& J. LANDIS, supra note 57, at 87-88. As one contemporary observer described review of their own decisions by district judges: "Such an appeal is not from Philip drunk to Philip sober, but from Philip sober to Philip intoxicated with the vanity of a matured opinion and doubtless also a published decision." Hill, The Federal Judicial System, in ABA, Report of the Twelfth annual. Meeting of the American Bar Association 289, 307 (1889).

59. The Circuit Courts of Appeals Act of 1891, ch. 517, 26 Stat. 826.

60. See Schaefer, Reducing Circuit Conflicts, 69 A.B.A. J. 452, 453-54 (1983). When the Evarts Act was debated in Congress, one concern was the risk of fragmenting national law. See 21 Conc. REc. 3407-08 (1890) (remarks of Rep. Breckinridge); id. at 10,221 (remarks of Sen. Evarts).

61. See Wasby, Inconsistency in the United States Courts of Appeals: Dimensions and Mechanisms for Resolution, 32 VAND. L. REv. 1343 (1979). For an example of such intracircuit discipline, see Ransom v. S\&S Food Center, 700 F.2d 670, 674 (11th Cir. 1983) (refusing to consider appel-
} 
court of appeals is bound to respect the decision of another on an issue of federal law. ${ }^{62}$ Indeed, when the Fifth Circuit was recently subdivided into the Fifth and Eleventh Circuits, the Eleventh Circuit had to act affirmatively to adopt Fifth Gircuit precedent, which otherwise would not have been binding. ${ }^{63}$ This independence does not make consistency between circuits irrelevant. Courts of appeals often endorse such uniformity as a matter of policy and strive to avoid conflicts. ${ }^{64}$ But real deference-unexamined adherence to the decisions of another circuit-is no substitute for the independent decisionmaking by each court of appeals that is inherent in the system created by the Evarts Act. ${ }^{65}$

The Evarts Act provided for resolution of intercircuit conflicts through Supreme Court review on writ of certiorari. The leading commentators on the Supreme Court's practice assert that uniformity of decision among the courts of appeals was a primary purpose of the certiorari jurisdiction. ${ }^{66}$ Although others disagree, ${ }^{67}$ the Supreme Court has identified the exis-

lant's argument, "even though we should be convinced of its correctness," because issue had already been resolved against appellant's position by circuit).

62. Newsweek v. United States Postal Serv., 663 F.2d 1186, 1196 (2d Cir. 1981), aff'd sub nom. National Ass'n of Greeting Card Publishers v. United States Postal Serv., 103 S. Ct. 2717 (1983); Western Oil \& Gas Ass'n v. EPA, 633 F.2d 803, 808 (9th Cir. 1980); 1B Moore's Federal. PracTICE, supra note 34, II 0.402[1], at 14-15 (circuits do not consider themselves bound by one another's decisions). For further discussion, see infra pp. 703-07.

63. See Bonner v. City of Prichard, 661 F.2d 1206, 1207 (11th Cir. 1981).

64. The best known expression of such sentiment is by Chief Judge Lay of the Eighth Circuit in Aldens, Inc. v. Miller, 610 F.2d 538 (8th Gir. 1979), cert. denied, 446 U.S. 919 (1980):

As an appellate court, we strive to maintain uniformity in the law among the circuits, wherever reasoned analysis will allow, thus avoiding unnecessary burdens on the Supreme Court docket. Unless our 11 courts of appeals are thus willing to promote a cohesive network of national law, needless division and confusion will encourage further splintering and the formation of otherwise unnecessary additional tiers in the framework of our national court system. Id. at 541. Although the burden of reading cases to keep up with developments reportedly occupies him 18 hours a day, Is Justice Short-Circuiled?, Nat'l L.J., Apr. 25, 1983, at 1, col. 1, Judge Lay has gone on record as opposing current proposals for a new court to resolve intercircuit differences. Lay, Query: Will the Proposed National Court of Appeals Create More Problems Than It Solves?, 66 JuDicature 437 (1983).

65. Nonetheless, requiring precisely such deference is advocated in Note, Securing Uniformity in National Lau: A Proposal for National Stare Decisis in the Courts of Appeals, 87 YALE L.J. 1219 (1978). The author urges federal adoption of an approach based on the California court system, in which, the Note asserts, decisions by the intermediate appellate courts bind the entire state until the state supreme court holds to the contrary. See $i d$. at $1232 \&$ n.83. In fact, however, the California system is also beset with conflicts. See Friedman \& Marer, The Appellate Dizisions Are Out of Control, 3 Cal. LAw., Apr. 1983, at 13.

66. R. Stern \& E. Gressman, Supreme Court Practice $\$ 4.4$ (5th ed. 1978).

67. Judge J. Clifford Wallace of the Ninth Circuit has recently argued that Congress' decision to give the Supreme Court jurisdiction to review only state court decisions that upheld state statutes against federal challenges suggests that it was more concerned with supremacy than uniformity. Wallace, The Nature and Extent of Intercircuit Conflicls: A Solution Needed for a Mountain or a Molehill?, 71 CALIf. L. REv. 913, 917-18 (1983). But this difference in treatment could also be explained on the ground that uniformity concerns are less important when the state statute is held invalid on federal grounds. $C f$. J. Nowak, R. Rotunda \& J. Young, Constitutional Law 33-34 (2d ed. 1983) (explaining fact that presently Supreme Court review of state court decisions invalidating state statutes on federal grounds is discretionary, while review is obligatory if state court upholds state 
tence of a conflict among the circuits as an important consideration in deciding whether to grant certiorari. ${ }^{\mathbf{B}}$

When conflicts developed among the circuits on important issues, the Supreme Court often resolved them. Two well-known recent examples should suffice. In Illinois Brick Co. v. Illinois, ${ }^{6 \theta}$ the Court resolved a conflict between circuits by holding that indirect purchasers lack standing to assert an antitrust claim for price fixing. ${ }^{70}$ In Ernst $\mathcal{E}$ Ernst $v$. Hochfelder, ${ }^{71}$ the Court held that proof of scienter is required to establish a claim for securities fraud under section 10(b) of the 1934 Securities Exchange Act, ${ }^{72}$ thereby rejecting the various formulations utilized by several courts of appeals that permitted recovery on a showing of negligence alone. ${ }^{73}$ Many more examples could be added.

The Supreme Court's eventual resolution of many intercircuit conflicts does not make these conflicts unimportant. Ordinarily there is a substantial delay between the first decision on a legal issue over which a conflict develops and an eventual resolution by the Supreme Court. ${ }^{24}$ During the interregnum, the lower courts must decide the cases before them, and undoubtedly plaintiffs in some circuits fare better than those in others precisely because of the differing approaches of the circuits. This disparity, in turn, may impose significant changes in interpretation upon transferred cases. ${ }^{78}$ Thus, even when the system works with reasonable dispatch, there is the potential for disparate results. Moreover, the Supreme Court is vulnerable to fragmentation akin to that in lower courts; the Court's actual resolution of issues often leaves room for continuing differences among the circuits. ${ }^{76}$

statute against federal challenge, partly on ground that in former situation there is no threat to uniformity of federal law).

68. See SuP. Cr. R. 19.1(b) (specifying conflict between circuits as ground for grant of certiorari).

69. 431 U.S. 720 (1977).

70. See id. at 728 \& n.8 (noting split in circuits).

71. 425 U.S. 185 (1976).

72. 15 U.S.C. $\S 78 \mathrm{j}(\mathrm{b})(1982)$.

73. 425 U.S. at 193 n.12 (discussing varying approaches of courts of appeals).

74. Illinois Brick provides an illustration. As the Supreme Court noted there in describing the conflict among the courts of appeals, 431 U.S. at $731 \mathrm{n} .8$, the first such decision by a court of appeals was in 1971, based on a district court decision in 1970. The conflict developed in 1973, when another court of appeals reached an opposite result. The Supreme Court resolved the conflict in 1977, four years after it developed and seven years after the first reported district court decision on the issue.

75. For an illustration resulting from the split in the circuits regarding standing of indirect purchasers to sue for price fixing, which the Court resolved in Illinois Brick, see infra p. 718.

76. For an examination of the Supreme Court's recent penchant for plurality and concurring opinions, see Davis \& Reynolds, Juridical Cripples: Plurality Opinions in the Supreme Court, 1974 Duke L.J. 59; Note, The Precedential Value of Supreme Court Plurality Decisions, 80 Colum. L. REv. 756 (1980). Some observers suggest that the increase in such plurality opinions contradicts assertions that Supreme Court Justices are overburdened. See Hellman, Caseload, Conflicts, and Decisional Capacity: Does the Supreme Court Need Help?, 67 Judicature 28, 32-33 (1983) (proliferation of separate opinions and disposition of unimportant cases suggest Court not overburdened). 
The Supreme Court's heavy caseload has made matters increasingly difficult. Commentators now regularly assert that the Court can no longer decide enough cases to resolve the existing conflicts among the circuits. ${ }^{77}$ Meanwhile, the exploding dockets of the courts of appeals and the attendant increases in the number of circuit judges have increased the likelihood of future conflicts not only between circuits but even within circuits. There is real concern that the number of intracircuit conflicts will rise geometrically as the number of judges on the larger courts mounts. ${ }^{78}$ The pressures to split circuits, which led to the subdivision of the Fifth Circuit, have therefore also increased. Indeed, a respected circuit judge recently predicted that there may eventually be a federal circuit for every state. ${ }^{79}$ While such fragmentation of circuits may reduce the frequency of intracircuit conflicts, it obviously multiplies the potential of intercircuit conflicts. $^{\text {Bo }}$

Over the last fifteen years, the prospect of increased conflicts has stimulated a number of proposals to create a new National Court of Appeals to resolve such conflicts. ${ }^{81}$ In 1983 , bills were introduced in both the Senate and the House to create a temporary Intercircuit Tribunal of the United States Courts of Appeals to perform that function. ${ }^{82}$ But the sense of Ar-

77. White, supra note 1, at 670; see Carrington, Crowded Dockets and The Courts of Appeals: The Threat to the Function of Review and the National Law, 82 HARv. L. Rev. 542, 580 (1969) ("The 'law of the circuit' has emerged as a response to the Supreme Court's incapacity to resolve intracircuit conflicts."). Efforts to verify these assertions have proved somewhat ambiguous. See Hellman, The Sujreme Court, the National Law, and the Selection of Cases for the Plenary Docket, 44 U. Pitr. L. Rev. 521 (1983).

78. For a discussion of the methods used by the Ninth Circuit, the largest circuit, to reduce intracircuit conflicts, see Lateef, Kepping Up With Justice: Automation and the New Activism, 67 JuDICATURE 213, 221 (1983).

79. Wallace, Working Paper-Future of the Judician', 94 F.R.D. 225, 229 (1981).

80. This is a debatable trade-off. See Mishkin, Observations, 42 Tex. L. REv. 1049, 1050-51 n.3 (1964) (intracircuit conflicts preferable to intercircuit conflicts because former can be resolved by en banc decision of circuit while latter can be resolved only by Supreme Court); Wright, The Oterloaded Fifth Circuil: A Crisis in Judicial Administration, 42 TEx. L. REv. 949, 973-74 (1964) (same).

81. For a review of the various proposals that have been made over the last fifteen years and the opposition they have provoked, see Meador, The Federal Judiciary-Inflation, Malfunction, and $a$ Proposed Course of Action, 1981 B.Y.U. L. REv. 617, 625-37. The original proposal for a National Court of Appeals is over a hundred years old, and was advanced as an alternative to circuit courts of appeals. See Swygert, The Proposed National Court of Appeals: A Threat to Judicial Symmetry, 51 IND. L.J. 327, 344 n.41 (1976).

82. See S. 455, 98th Cong., 1st Sess., 129 Cong. Rec. S1948, S1956 (daily ed. Mar. 1, 1983); H.R. 1970, 98th Cong., 1st Sess., 129 Cong. Rec. H1192-93 (daily ed. Mar. 15, 1983). The characteristics of any tribunal that might be created remain uncertain. The original House and Senate bills closely resemble one another, calling for the creation of a tribunal staffed by twenty-seven or twentyeight sitting judges of the courts of appeals, selected by the circuit councils. Cases would be referred to the new tribunal by the Supreme Court and decided by randomly selected panels of five judges. Unless modified by the Supreme Court, these decisions would bind the courts of appeals. The proposed tribunal would go out of existence after an experimental period of five years. On June 29, 1983, the Subcommittee on Courts of the Senate Judiciary Committee reported out the Senate version with substantial amendments. As amended, the Senate bill calls for an en banc court with nine judges and four alternates, designated by a majority of the Supreme Court and sitting for staggered terms. S. 645, 98th Cong., 1st Sess. (Subcomm. Print 1983) (on file with author). 
mageddon is far from universal, and proposals for reform have provoked spirited opposition. Opponents of the new court argue that its creation would undermine the Supreme Court's function and sense of responsibility ${ }^{83}$ Some claim that the Supreme Court remains capable of resolving all "genuine" conflicts. ${ }^{84}$ Others contend that divergent interpretations of federal law actually help the Supreme Court because they fully air issues before the Court is called upon to decide them. ${ }^{85}$ It has even been suggested that regional disparities in interpreting federal law are desirable. ${ }^{88}$ Given this opposition, it is unclear whether Congress will create an Intercircuit Tribunal any time soon. ${ }^{87}$

Beyond these political considerations, the likelihood that the proposed Intercircuit Tribunal would eliminate conflicts between the circuits is small. At best this body would be a stop-gap measure that, with its possibly shifting membership, ${ }^{88}$ offers little hope for a long-term solution. If a more permanent court is created some day, ${ }^{89}$ conflicts between the circuits

Chief Justice Burger has endorsed this temporary measure and urged that another congressional commission be created to formulate a more permanent solution. See Burger, supra note 1, at 445, 447 (1983). The Chief Justice, however, does not see the proposal as a panacea. On the contrary, his endorsement is quite qualified: "I assure you at the outset that if I knew precisely how to solve this problem I would not hesitate to say so, but I do not have the answers." Id. at 444.

83. See Brennan, The National Court of Appeals: Another Dissent, 40 U. CHI. L. REv. 473, 480-85 (1973).

84. See G. Casper \& R. Posner, The Workload of the Supreme Court 89-90 (1976); Hellman, How Not to Help the Supreme Court, 69 A.B.A. J. 750, 753-54 (1983); Wallace, supra note 67 , at 928-29. Indeed, there is sometimes a dispute about what should be labelled a conflict. Compare Stern, Denial of Certiorari Despite a Conflicl, 66 HaRv. L. Rev. 465, 472 (1953) (Court takes factors other than conflict among circuits into account in granting certiorari) with Roehner \& Roehner, Certiorari-What is a Conflict Between Circuits?, 20 U. CH1. L. REv. 656, 664 (1953) (Court grants certiorari whenever there is "head-on collision" between circuits).

85. See Hellman, supra note 76, at 37 ("the judicial system's analogue to the adversary process"); McGarity, Multi-Party Forum Shopping for Appellate Review of Administrative Action, 129 U. PA. L. REv. 302, 318-19 (1980). For a recent example of this view on the Court, see Justice Stevens' opinion respecting denial of certiorari in McCray v. New York, 103 S. Ct. 2438, 2438 (1983) ("I believe that further consideration of the substantive and procedural ramifications of the problem by other courts will enable us to deal with the issue more wisely at a later date.").

86. See Hruska Commission, supra note 1, at 235 (rejecting specialized nationwide courts as solution to burden of appellate caseload because they "would tend to dilute or eliminate regional influence in the decision of those cases").

87. The pending bills, see supra note 82 , have provoked powerful opposition. Justice Stevens and the Reagan Administration have publicly opposed the House bill, see N.Y. Times, Nov. 11, 1983, at A32, col. 1, and two circuits' chief judges have testified against it, see Four Circuit Chief Judges Differ in Congressional Testimony on Proposed Intercircuit Tribunal, 15 ThIRd BRANCH, Nov. 1983, at 3. For an academic attack, see Hellman, supra note 76.

88. A system calling for decisions by five judges chosen by lot from among twenty-seven members of a court with shifting membership, see supra note 82 , hardly suggests great consistency of attitude among panels. Even the Senate's amended bill, proposing a court of nine members and four alternates, raises substantial concern about variations in personnel. In this connection, it is worth noting that the congressional commission that studied the problem rejected manning its proposed court on a rotating basis because "[a] court so composed would lack the stability and continuity that are essential to the development of national law." Hruska Commission, supra note 1, at 237-38.

89. Congressional action may not occur until the 1990's. To illustrate, in a 1981 article, Professor Daniel Meador, a proponent of reform, suggested a timetable leading to a legislative solution by 1989. 
will not magically vanish. There will still be a delay between the appearance of a conflict and its resolution by the new tribunal. Moreover, the new court may be unable to resolve issues as definitively as the Supreme Court can. ${ }^{90}$ Perhaps most significantly, the widespread perception among lawyers that the circuits have different attitudes toward certain issues will endure. ${ }^{91}$ Although more frequent review of court of appeals decisions might iron out such differences, ${ }^{92}$ the belief that one circuit views particular claims more charitably than another is likely to persist.

Thus, while modification of the appellate system may reduce conflicts among circuits, ${ }^{93}$ incentives to engage in forum shopping will persist. The question here is not whether such forum shopping is inherently bad, ${ }^{84}$ but only whether the effort to capture a favorable interpretation, or merely a friendly reception, should be immunized against a transfer from one circuit to another. The ongoing debate about reforming the federal appellate machinery is no reason to disregard that question.

Spe Meador, supra note 81, at 653-58. But his timetable depended on the creation by 1982 of a new congressional commission to study the issues. This commission was never formed.

90. Even the Supreme Court itself sometimes provides less-than-definitive resolutions of important questions. See supra p. 688.

91. The existence of such perceptions is difficult to prove, but they do exist. See infra note 159. This view is confirmed by reports that among lawyers seeking review of action by administrative agencies, different circuits acquire different reputations. See Brecher, Venue in Conservation Cases: $A$ Potential Pilfall for Entironmental Lauyers, 2 EcoLOGY L.Q. 91, 94 (1972); McGarity, supra note 85, at 310 \& n.42; Comment, Forum-Shopping in the Review of NLRB Orders, 28 U. CHI. L. REv. 552, 558-61 (1961); Note, Forum-Shopping in Appellate Review of FTC Cease and Desist Orders, 1968 Utah L. Rev. 316, 316 n.3. Indeed it seems that such perceptions exist inside Congress. See Sunstcin, Participation, Public Law, and Venue Reforn, 49 U. CHI. L. REv. 976, 979 (1982) (proposals for venue reform of administrative review motivated by hostility to "liberal" District of Columbia Circuit).

92. Sep Griswold, Rationing Justice-The Supreme Court's Caseload and What the Court Does Not Do, 60 Cornell L. REv. 335, 341-42 (1975) (arguing that courts of appeals lack "institutional responsibility" about avoiding conflicts because they know their decisions will not be reviewed; if ten percent of court of appeals decisions were reviewed, "the law would soon be clarified and stabilized").

93. Conflicts are easy to identify at present. In the securities area, the courts conflict on whether the sale of all stock in a business should be treated as a transaction involving the sale of securities within the meaning of the 1934 Securities Exchange Act. Compare Daily v. Morgan, 701 F.2d 496 (5th Cir. 1983) (sale of $100 \%$ of stock is covered by federal securities laws) and Golden v. Garafalo, 678 F.2d 1139 (2d Cir. 1982) (same) with King v. Winkler, 673 F.2d 342 (11th Cir. 1982) (sale of $100 \%$ of stock not covered by federal securities laws). Similarly, the courts are split on whether respondeat superior is available to establish liability under section 10(b) of the 1934 Securities Exchange Act, 15 U.S.C. $\$ 78 \mathrm{j}$ (b) (1982). Compare Zweig v. Hearst Corp., 521 F.2d 1129, 1132-33 (9th Cir.) (respondeat superior inapplicable), cert. denied, 423 U.S. 1025 (1975) with Marbury Management, Inc. v. Kohn, 629 F.2d 705, 716 (2d Cir.) (respondeat superior applicable), cert. denied, 449 U.S. 1011 (1980). In the civil rights area, there is a conflict regarding the res judicata effect in Title VII cases of determinations of state tribunals. Compare Sinicropi v. Nassau County, 601 F.2d 60 (2d Cir.) (per curiam) (res judicata bars subsequent federal action), cert. denied, 444 U.S. 983 (1979) with Cooper v. Philip Morris, Inc., 464 F.2d 9 (6th Cir. 1972) (res judicata inapplicable). In the antitrust area, for a survey of different approaches to rule of reason analysis, see Pollock, The Antitrust Jurisprudence of the Setenth Circuit, 38 REC. A.B. CrTY N.Y. 308, 320-30 (1983).

94. Cf. Ely, The Irrepressible Myth of Erie, 87 HARv. L. REv. 693, 710 (1974) ("[F]orum shopping is not an evil per se. It is evil only if something evil flows from it; indeed, the very idea of the diversity jurisdiction was to provide an alternative to state court.") (footnote omitted). 


\section{The Inapplicability of the Principles Underlying Van Dusen to Transfers of Federal Glaims}

However troubling conflicts among the circuits may be from the perspective of judicial administration, they ordinarily do not present choiceof-law problems in the resolution of individual cases. Instead, a court applying federal law to a given case analyzes the strengths and weaknesses of the contending approaches advanced by the parties. Such analysis often involves examining relevant decisions by courts in other circuits, but only as aids to interpretation, not as binding determinations.

A transfer complicates matters, however, when it moves a case from a circuit in which one interpretation applies to another circuit in which a conflicting interpretation prevails. As shown in Part III, the number of intercircuit conflicts is substantial. There is, however, no way to determine how often a transfer moves a case to a circuit with an interpretation that conflicts with the transferor's, but the number of transfers of federal claims is also substantial. In 1965, Professor Edmund Kitch reported that approximately forty percent of all cases transferred under section 1404(a) involved claims based on special federal jurisdictional statutes. ${ }^{95}$ Given the increase in the number of cases raising federal claims since then, ${ }^{96}$ it is reasonable to assume that a significant proportion of all transfers under section 1404(a) are federal claims. Transfers of federal claims cases under the multidistrict litigation statute are also numerous, given the frequency of multidistrict treatment of securities and antitrust cases. ${ }^{97}$ Thus sheer numbers show that the problem is significant.

Before Van Dusen was decided, several lower courts asserted that differences in interpretation of federal law were irrelevant to the decision whether to transfer, and that the transferee court should decide the issues of federal law without regard to the views of the transferor circuit. ${ }^{98} \mathrm{Van}$ Dusen was expressly limited to differences in state law, ${ }^{98}$ but after it was decided many lower courts concluded-without analysis-that its reasoning would govern transferred federal claim cases as well.100 In many such

95. Kitch, Section 1404(a) of the Judicial Code: In the Interest of Justice or Injustice?, 40 IND. L.J. 99,137 n.179 (1965).

96. The proportion of civil filings that raise federal claims has steadily increased since the mid1960's. See Kirkham, Problems of Complex Cizil Litigation, 83 F.R.D. 497, 499-500 (1979). For figures on the number of cases transferred pursuant to $\S 1404(\mathrm{a})$ in recent years, see supra note 16.

97. Transfers under the multidistrict litigation statute are particularly frequent in securities and antitrust cases. Of the 112 groups of transfers ordered by the Multidistrict Panel prior to 1974, 63 (or $56 \%$ ) were in antitrust or securities litigation. Note, supra note 18, at 1003 n.13.

98. H.L. Green Co. v. MacMahon, 312 F.2d 650, 652 (2d Cir. 1962), cert. denied, 372 U.S. 928 (1963); Ackert v. Bryan, 299 F.2d 65, 69-70 (2d Cir. 1962); Clayton v. Warlick, 232 F.2d 699, 706 (4th Cir. 1956).

99. 376 U.S. at $625-26,630,633,635,639$.

100. Berry Petroleum Co. v. Adams \& Peck, 518 F.2d 402, 408 n.7 (2d Cir. 1975); Sargent v. Genesco, Inc., 492 F.2d 750, 758 (5th Cir. 1974); Sentner v. Amtrak, 540 F. Supp. 557, 559 n.5 
instances, however, the actual issue was selection of the state law that would provide the limitations period for the federal claim, not interpretation of federal law. ${ }^{101}$ A few lower courts continued to disregard transferor law. ${ }^{102}$ None gave the question much attention, however.

To determine whether Van Dusen should apply to the transferred federal claims, we must analyze the applicability of its rationale to such cases. An examination of the two principal grounds for that decision-the Erie doctrine and the notion that the venue privilege gives plaintiff a right to the transferor court's interpretation-shows that neither provides a basis for applying Van Dusen to transferred federal claims.

\section{A. The Policy Underlying Erie}

Seemingly as a backstop for its acquired rights interpretation of section 1404(a), the Court in Van Dusen explained that its holding "fully accord[ed] with and is supported by the policy underlying Erie $R$. Co. v. Tompkins."103 This seems strong support indeed, for Erie looms over all federal adjudication. ${ }^{104}$ It has been described as "the most studied principle in American law"10s and the "keystone of the procedure course."108 Nevertheless, it is irrelevant to the choice-of-law problem with transferred federal claims for two reasons.

(D.N.J. 1982); Thorn v. New York City Dep't of Social Servs., 523 F. Supp. 1193, 1198 (S.D.N.Y. 1981); In re National Student Mktg. Litig., 517 F. Supp. 1345, 1346 n.3 (D.D.C. 1981); Campbell v. Upjohn Co., 498 F. Supp. 722, 726 (W.D. Mich. 1980), aff'd, 676 F.2d 1122 (6th Cir. 1982); In re Haven Indus. Sec. Litig., 462 F. Supp. 172, 179 (S.D.N.Y. 1978); Oldfield v. Alston, 77 F.R.D. 735, 743 n.2 (N.D. Ga. 1978); Brick v. Dominion Mortgage \& Realty Trust, 442 F. Supp. 283, 299 (W.D.N.Y. 1977); In re Clinton Oil Co. Sec. Litig., [1977-1978 Transfer Binder] FED. SEC. L. REP. (CCH) If 96,015, at 91,566-67 (D. Kan. Mar. 18, 1977); Stirling v. Chemical Bank, 382 F. Supp. 1146, 1150 n.5 (S.D.N.Y. 1974), appeal dismissed, 511 F.2d 1030 (2d Cir.), aff'd, 516 F.2d 1396 (2d Cir. 1975); In re Four Seasons Sec. Laws Litig., 370 F. Supp. 219, 228 (W.D. Okla. 1974); Corey v. Bache \& Co., 355 F. Supp. 1123, 1125 (S.D.W. Va. 1973); In re Plumbing Fixtures Litig., 342 F. Supp. 756, 758 (J.P.M.D.L. 1972); Philadelphia Hous. Auth. v. American Radiator \& Standard Sanitary Corp., 309 F. Supp. 1053, 1055 (E.D. Pa. 1969); cf. Harriman v. E.I. Du Pont de Nemours \& Co., 411 F. Supp. 133, 151-52 (D. Del. 1975) (where transferred state claims are pendent to federal claims, Van Dusen applies).

101. Sep infra pp. 708-09.

102. Sep Roth v. Bank of the Commonwealth, [1981-1982 Transfer Binder] FED. SEc. L. REP. (CCH) II 98,267, at 91,712 (W.D.N.Y. Aug. 17, 1981); Scheinbart v. Certain-Teed Prods. Corp., 367 F. Supp. 707, 710-11 (S.D.N.Y. 1973). Without directly addressing the issue, some post-Van Dusen decisions assume that after a transfer the transferee court would apply its own interpretation of federal law. See Cheeseman v. Carey, 485 F. Supp. 203, 215 (S.D.N.Y. 1980); Ziegler v. Dart Indus., 383 F. Supp. 362, 364-65 (D. Del. 1974) (fact that plaintiff would enjoy favorable change of law due to transfer insufficient to justify transfer on plaintiff's $\S 1404(a)$ motion).

103. 376 U.S. at 637 .

104. Cf. Clark, State Law in the Federal Courls: The Brooding Omnipresence of Erie v. Tompkins, 55 YALE L.J. 267, 269 (1946) (ascribing quotation to Learned Hand: "I don't suppose a civil appeal can now be argued to us without counsel sooner or later quoting large portions of Erie Railroad v. Tompkins.").

105. Westen \& Lehman, Is There Life for Erie After the Death of Ditersity?, 78 Mrch L. REv. 311,312 (1980).

106. Younger, What Happened in Erie, 56 TEx. L. REv. 1011, 1011 (1978). 
First, Erie is limited to issues of state law. The Court there expressly excluded "matters governed by the Federal Constitution or by Acts of Congress" ${ }^{\prime 107}$ from its ruling that federal courts are bound by state law in other matters. Swift $v$. Tyson ${ }^{108}$ had authorized the federal courts to devise rules of decision even for issues not governed by federal law. Erie rejected Swift's premise that there was "a transcendental body of law outside of any particular State but obligatory within it." ${ }^{109}$ As Justice Frankfurter explained in Guaranty Trust Co. v. York, that assumption was stimulated by "the attractive vision of a uniform body of federal law."110 Even though that vision has been clouded by conflicts between the circuits, matters are obviously different when the claim arises under federal law. Thus, while in Guaranty Trust the Court held that in a diversity case a federal court is required to apply the state's statute of limitations, less than a year later in Holmberg $v$. Armbrecht ${ }^{111}$ the Court emphasized the difference between federal claims and state claims by holding Erie inapplicable to a limitations issue for a federal claim: "The considerations that urge adjudication by the same law in all courts within a State when enforcing a right created by that State are hardly relevant for determining the rules which bar enforcement of an equitable right created not by a State legislature but by Congress."112 Erie simply does not apply to federal claims.

Second, the "policy underlying Erie," cited by the Court in Van Du$s e n,{ }^{113}$ is also irrelevant. Identifying Erie's policy is not an easy matter; debate about the importance of various proffered policies continues. ${ }^{114}$ But it is enough for present purposes to analyze two of Erie's concerns that pertain to the transfer situation. ${ }^{115}$ First, as Justice Brandeis emphasized

107. Erie R.R. Co. v. Tompkins, 304 U.S. 64, 78 (1938).

108. 41 U.S. (16 Pet.) 1 (1842).

109. 304 U.S. 64, 79 (quoting Black \& White Taxicab \& Transfer Co. v. Brown \& Yellow Taxicab \& Transfer Co., 276 U.S. 518, 533 (1928) (Holmes, J., dissenting)).

110. 326 U.S. 99,103 (1945).

111. 327 U.S. 392 (1946).

112. Id. at 394 .

113. The Court referred to the policy underlying Erie when deciding Van Dusen, 376 U.S. 637, but the issue in Van Dusen is outside the normal Erie debate whether a federal or state rule should be applied to a certain issue. In Van Dusen, there was no question that state law should govern; the only question was which state's law.

114. Compare Ely, supra note 94, at 712-13 (emphasizing fairness to litigants) with Redish \& Phillips, Erie and the Rules of Decision Act: In Search of the Appropriate Dilemma, 91 HARv. L. REV. 356, 376-77 (1977) (arguing that fairness to litigants is not significant).

115. One oft-mentioned Erie concern-deterring forum shopping-seems to have little relevance and was not alluded to by the Court in Van Dusen. Presumably the reason is that any rule promotes one type of forum shopping and prevents another. Thus, the Court's holding in Van Dusen overtly protects the benefits of plaintiffs' forum shopping (under the acquired rights rubric) and precludes forum shopping by defendants via $\S 1404(\mathrm{a})$ motions. The opposite holding would, of course, have reduced the incentives for plaintiffs to forum shop and increased the incentive for defendants to use $\S 1404$ (a) motions for that purpose. 
in Erie, it is unfair to discriminate between those who can gain admission to federal court on the basis of diversity and those who are confined to state court by the fortuity of their residence. ${ }^{110}$ So viewed, Erie seeks to assure that the result would be the same in either court. Second, Erie guards the integrity of state policy. As the Court explained in Klaxon, it "leaves to a state ... the right to pursue local policies diverging from those of its neighbors."

The Van Dusen Court rightly concluded that these concerns would be imperiled if courts interpreted section 1404(a) to give defendants "a change of law as a bonus for a change of venue" in transferred diversity cases. ${ }^{118} \mathrm{Had}$ Massachusetts law been substituted for Pennsylvania law in Van Dusen because of a transfer, which would not have been available in state court, the outcome would have been different due to the accident of diversity that allowed the case into federal court. ${ }^{119}$ Allowing the "procedural" device of transfer to effect such a change in the substantive law would unfairly distinguish between litigants on the basis of residence and thus would violate the first principle of Erie.

A change from Pennsylvania law to Massachusetts law would also threaten the policies and interests of Pennsylvania. At the time the Court decided Van Dusen, it was unclear whether the Pennsylvania courts would choose to apply their own measure of damages or the Massachusetts measure. ${ }^{120}$ Subsequent developments indicated that the Pennsylvania courts would apply their own law, ${ }^{121}$ thereby showing Pennsylvania's interest in assuring compensation. Substituting Massachusetts' truncated measure of damages would have frustrated that interest. This protection of state policy is also consistent with Erie.

116. For a criticism of this concern, see Redish \& Phillips, supra note 114, at 376-77.

117. Klaxon Co. v. Stentor Elec. Mfg. Co., 313 U.S. 487, 496 (1941), quoted in Van Dusen, 376 U.S. at 638 n.38.

118. Wells v. Simonds Abrasive Co., 345 U.S. 514, 522 (1953) (Jackson, J., dissenting), quoted in Van Dusen, 376 U.S. at 636 n.33.

119. Arguably the availability of transfer itself raises Erie problems in diversity cases, but as a "judicial housekeeping" matter regulating venue in the federal system, the statute surely may be applied in diversity cases despite Erie. See supra p. 685. Given this interpretation, $\S 1404$ (a) must be within Congress' power under article I of the Constitution, just as the Rules Enabling Act was, and therefore the application of the transfer statute to diversity cases is proper despite Erie. See Hanna v. Plumer, 380 U.S. 460 (1965). By way of contrast, the question whether common law forum non conveniens is governed by state law or federal law in diversity cases has yet to be resolved by the Supreme Court. See Piper Aircraft Co. v. Reyno, 454 U.S. 235, 248 n.13 (1981). Commentators have concluded, however, that forum non conveniens is a matter of federal law in diversity cases. See 15 Federal Practice \& Procedure, supra note 14, $\$ 3847$, at 237-39; 1 MoORe's Federal PracTICE, supra note $34, \uparrow 0.145$ [3.-1], at 1584.

120. See 376 U.S. at 628-29.

121. See Griffith v. United Air Lines, 416 Pa. 1, 203 A.2d 796 (1964). On remand in Van Dusen, the district judge read Griffith as indicating that Pennsylvania would apply its own law, but also acknowledged that "Griffith is still a mystery to us." Popkin v. Eastern Air Lines, 253 F. Supp. 244, 249 n.7 (E.D. Pa. 1966). 
These same considerations do not apply to federal claims. The problem of unfairness vanishes because all litigants can gain access to federal court regardless of citizenship. ${ }^{122}$ Concerns over state policy are similarly unimportant where federal claims are involved. If state policies are inconsistent with federal law, they must give way under the supremacy clause. ${ }^{123}$ Moreover, there is no federal or circuit interest in the application of a particular interpretation of federal law that is analogous to the interest a state might have in the application of its law to a particular case. Indeed, because the lower federal courts are to construe federal law independently, the true federal interest is having the court which decides the case apply its own interpretation of federal law.

\section{B. Acquired Rights and the "Venue Privilege"}

Van Dusen emphasized the advantages flowing from exercise of plaintiff's "venue privilege" as a predicate for its holding that, as to issues of state law, Congress did not intend a transfer under section 1404(a) to eliminate those advantages. ${ }^{124}$ But Van Dusen did not articulate any theoretical basis for concluding that, by exercising the venue privilege, plaintiff acquires the right to have a certain state's law apply. Analysis ultimately leads to the conclusion that there is none. Instead, the Court's emphasis on the venue privilege appears to result from the absence of federal principles for choice of state law, turning the selection of law into a game of chess in which the plaintiff gets the opening move. ${ }^{125}$ The overlay of a federal system that permits transfer to a court sitting in a different state makes the value of that first move even more significant by precluding dismissal on grounds of forum non conveniens which would result in a change of law.

The plaintiff's venue privilege and the resultant choice-of-law advantages are deeply ingrained in our jurisprudential psyche. Professor Moore,

122. Sep 28 U.S.C. § 1331 (1976 \& Supp. V 1981) (federal question jurisdiction); id. § 1441(a) (1976) (removal jurisdiction). For an expansion of this argument, see Westen \& Lehman, supra note 105 , at $378-85$.

Arguably the potential for a change in result due to the transfer of a federal claim from one circuit to another creates an analogous risk of unfairness, but this issue has no bearing on the discussion in the text for two reasons. First, the "unfairness" does not result from the accident of diversity and it is therefore not the same as the Erie concern. Second, and more important, there is simply no unfairness in view of the principle of competence discussed infra at Part V. To the contrary, parties have no right to select a preferred interpretation of federal law. See infra pp. 706-07. Where the initial forum is sufficiently inconvenient to justify a transfer, the parties can hardly object to a possible difference in interpretation of federal law.

123. U.S. ConST. art. VI, cl. 2.

124. See 376 U.S. at 633-34.

125. Cf. Currie, supra note 38 , at 441 (describing change of venue as "game of chess, with Section 1404(a) authorizing a knight's move; and nothing would be certain except that the parties would land on a square of a different color") (footnote omitted), quoted in Van Dusen, 376 U.S. at 636 n.34. 
who originally proposed section 1404(a), has argued that even where plaintiff himself moves to transfer he should be permitted to keep the state law of the original forum so long as it was a proper venue. ${ }^{128} \mathrm{He}$ reasons that plaintiff has a right to insist on keeping the case there (or make defendant move to transfer, thereby invoking $\operatorname{Van} D$ usen), so that the fact that plaintiff takes the initiative regarding transfer should be unimportant. Another commentator has suggested that even if the state in which the case was originally filed would dismiss on grounds of forum non conveniens, the applicable state law should remain unchanged after a transfer under section 1404(a). ${ }^{127}$ The argument is that the state court dismisses only because it has no other way to move the case to the appropriate forum, not to effect a change in law. Since section 1404(a) allows such a transfer in the federal court system, the incidental change of law that attends a dismissal need not carry over into the federal system. Thus, there is a pervasive inclination to leave the choice of state law to the plaintiff if he complies with venue and jurisdictional limitations.

The problem with this approach is that choice-of-law decisions do not flow naturally from venue provisions. Although a determination of venue may involve some considerations pertinent to choice of law, venue traditionally has focused on geographic convenience to defendant by limiting the number of locations in which plaintiff may file suit. ${ }^{128}$ Venue reform has therefore addressed the relative burdens on plaintiffs and defendants of litigating at a distance. When Congress has concluded that the burden was unfair to plaintiffs it has expanded the number of venues available to the plaintiff, as it did by amending the Federal Employer's Liability Act ${ }^{129}$ and by enacting a broad general venue provision for suits against corporations. ${ }^{130}$ This focus on geographical convenience is also reflected in forum non conveniens decisions, where courts repeatedly emphasize the legitimacy of plaintiffs' decisions to sue at home. ${ }^{131}$ Identifying the con-

126. 1 Moore's Federal Practice, supra note 34, T0 0.145 [4.-5], at 1608; see Note, Choice of Law in Federal Court After Transfer of Venue, 63 CoRnell L. REv. 149, 157-58 (1977). But see 15 Federal Practice and Procedure, supra note 14, § 3846, at 234; Currie, The Federal Courts and the American Law Institute: Part II, 36 U. CHI. L. REv. 268, 310 (1969). In Van Dusen the Court reserved this question. See supra p. 685.

127. Note, Erie, Forum Non Conveniens and Choice of Law in Dizersity Cases, 53 VA. L. Rev. 380, 390-91 (1967). Where either jurisdiction or venue was improper in the original venue, however, a transfer works a change of law. E.g., Nelson v. International Paint Co., 716 F.2d 640, 643 (9th Cir. 1983); Ellis v. Great Southwestern Corp., 646 F.2d 1099, 1109-11 (5th Cir. 1981).

128. Sep generally 15 Federal PRActice \& Procedure, supra note $14, \S 3801$, at $4 ; 1$ MoORe's Federal Practice, supra note 34, J 0.140 [1.-1].

129. See 45 U.S.C. $\$ 56$ (1976). For a discussion of the unfairness to plaintiffs that led to the broad venue provision, see Baltimore \& O.R.R. Co. v. Kepner, 314 U.S. 44, 49-50 (1941).

130. Sep 28 U.S.C. \$1391(c) (1976). For a discussion of the inconvenience to plaintiffs before $\S 1391$ (c) was added in 1948, see 15 Federal Practice \& Procedure, supra note 14, § 3811, at 551; MoOre's Federal Practice, supta note 34, I 0.140 [1.-1].

131. E.g., Piper Aircraft Co. v. Reyno, 454 U.S. 235, 255-56 (1981); Koster v. Lumbermens 
venient or fair location for a suit, however, has no inherent connection to selecting the source of law that should govern the case. In expanding the available venues under the F.E.L.A., for example, Congress sought to relieve plaintiffs of the burden of traveling long distances to sue their employers, not to enable them to travel long distances to capture favorable law. With improvements in transportation and communication, however, it has become increasingly easy for plaintiffs to roam far afield to do precisely that.

Transfer of venue brings the intended and unintended effects of broad venue into sharp and ironic focus. As Professor Edmund Kitch has observed, "the congressional policy of the venue provision to favor the plaintiff is in irreconcilable conflict with the congressional policy incorporated in the transfer section to protect the defendant against an inconvenient forum." 132 The transfer section is intended, on a case-by-case basis, to accomplish the original objective of venue provisions and limit a plaintiff's ability to impose undue geographical burdens on a defendant. Once plaintiff's original choice of forum has been overridden by a transfer, the reason for giving plaintiff a broad choice of venues in the first place ceases to apply. Indeed, any connection between the convenience of the forum and the choice of law would point to preferring the law of the transferee. Ironically, however, even though his choice of location has been taken away from him, plaintiff's incidental choice of law is still protected under a theory of acquired rights.

Piper Aircraft Co. v. Reyno, ${ }^{138}$ a 1981 Supreme Court decision, shows that there is little inherent force to the acquired rights notion, particularly when balanced against concerns about forum shopping. In Piper, the Gourt held that the prospect of a significant change in law is immaterial to the decision whether to dismiss on grounds of forum non conveniens. The claims there arose out of an airplane crash in Scotland that killed five Scottish citizens. Since Scottish law apparently did not authorize product liability claims, plaintiffs hired a California lawyer ${ }^{134}$ who had his secretary appointed administratrix of the estates of the decedents to take advantage of American strict liability law. ${ }^{135}$ The secretary-administratrix filed

\footnotetext{
Mut. Casualty Co., 330 U.S. 518, 524-25 (1947).

132. Kitch, supra note 95, at 137; see also von Mehren, Adjudicatory Jurisdiction: General Theories Compared and Evalualed, 63 B.U.L. Rev. 279, 324 (1983).

133. 454 U.S. 235 (1981).

134. There is no explanation in the record of how plaintiffs' relationship with the California lawyer was established, but it appears that this was not the only such action he handled. In Whyham v. Piper Aircraft Corp., 96 F.R.D. 557 (M.D. Pa. 1982), the same lawyer brought suit on behalf of persons killed in another accident in Scotland. Noting that Regno involved "facts nearly identical to this action," id. at 562, the district court dismissed. This case lends credence to the Court's concern about a substantial influx of foreign litigation into the United States.

135. Plaintiff acknowledged that the suit was filed in the United States to take advantage of
} 
wrongful death claims in California state court against Piper, which manufactured the plane, and an Ohio company that manufactured the propeller. Venue was proper under California law anywhere in the state, because neither defendant was a California resident, ${ }^{136}$ but the Ohio company was not subject to personal jurisdiction in California. Defendants removed to federal court, obtained a transfer under section 1404(a) to Pennsylvania, and then moved to dismiss on forum non conveniens grounds because Scotland would be a more convenient forum. The district court granted defendants' motion, but the Third Circuit reversed on the theory that dismissal on grounds of forum non conveniens was not permissible if the consequence would be an adverse change of law for plaintiff. ${ }^{137}$

Without dissent, ${ }^{138}$ the Supreme Court rejected the Third Circuit's position and held that no substantial weight should be given to the prospect of a change of law in deciding a forum non conveniens motion. ${ }^{138}$ In part, the Court reacted to the spectre that large numbers of foreign plaintiffs injured by products manufactured in the United States would sue in this country to take advantage of favorable American products liability law. ${ }^{\mathbf{1 4 0}}$ Implicitly, however, the Gourt also rejected a broad view of the notion that a plaintiff who has sued in a proper venue acquires a right to the law applied there. By the time the motion to dismiss was decided in the Pennsylvania district court, both venue and jurisdiction requirements were unquestionably satisfied. Plaintiff had exercised her "venue privilege," and had even advanced an arguable American interest in application of American product liability laws: Since American firms market their products domestically as well as overseas, American courts should apply domestic law to deter the harmful activities giving rise to the claim and thereby protect American citizens. ${ }^{141}$

The Court was unpersuaded. It held that where trial in the forum selected by the plaintiff would impose a heavy burden on the defendant or

American law. Sep 454 U.S. at 240.

136. Cal. Crv. Proc. Code § 395(a) (West 1973 \& Supp. 1983).

137. 630 F.2d 149, 163-64 (3d Cir. 1980), rev'd, 454 U.S. 235 (1981). Judge Henry Friendly has questioned the Supreme Court's characterization of the Third Circuit decision as relying entirely on the change in law. See Friendly, Indiscretion About Discretion, 31 Emory L.J. 747, 749 \& n.4 (1982).

138. Neither Justice Powell nor Justice O'Connor took part in the decision. Justices Brennan, White, and Stevens joined the Court in rejecting the Third Circuit's reliance on the potential change in the law but dissented from the majority's decision to go on and decide other matters. See 454 U.S. at 261-62.

139. The Court did acknowledge that a change in law would be significant if, as a result of dismissal, plaintiff were "deprived of any remedy." Id. at 254-55. It is not clear whether that reasoning would apply if, for example, the foreign jurisdiction would hold the claim barred by the statute of limitations.

140. See 454 U.S. at 251-52.

141. Id . at 260-61. The Court found that "the incremental deterrence that would be gained if this trial were held in an American court is likely to be insignificant." Id. 
the court, dismissal would be proper unless plaintiff could offer "specific reasons of convenience supporting his choice." ${ }^{142}$ Such a showing would be difficult, the Court suggested, where plaintiff chose the forum "solely in order to . . . take advantage of favorable law." "143 Further, noting that due to broad venue provisions plaintiffs would ordinarily choose the forum with favorable law, ${ }^{144}$ it emphasized that "the deference accorded a plaintiff's choice of forum has never been intended to guarantee that the plaintiff will be able to select the law that will govern the case."146 Rather than condone use of the venue privilege to capture favorable law, the Court condemned it. The Court distinguished Van Dusen on the ground that a dismissal for forum non conveniens differed from a transfer under section 1404(a) because the latter allowed "easy change of venue within a unified federal system." ${ }^{\text {"146 }}$ Although the international character of Reyno did distinguish it from section 1404(a) situations, ${ }^{147}$ at bottom the case showed that the Court places little faith in the acquired rights theory.

Why then did Van Dusen place such emphasis on acquired rights? The answer is essentially the reason Professor Currie eventually threw up his hands in despair: There are no federal choice-of-law principles that favor application of the law of one state over the law of another. ${ }^{148}$ Admittedly, the due process clause does prevent a state from applying its own law to a case with which it has no substantial contacts. ${ }^{19}$ But a number of states

142. Id. at 249 (footnote omitted).

143. Id. at 249 n.15.

144. Id. at 250 .

145. Id. at 257 n.24.

146. II. at 253-54. In part this reasoning relied on the need for a stronger showing of inconvenience to justify a forum non conveniens dismissal than a transfer under $\S 1404$ (a). But even where a showing sufficient to justify dismissal has been made, dismissal is not allowed if the case can be transferred to the more convenient forum. See supra p. 683. Thus the difference in showing required has little to do with preservation of the advantage gained by plaintiff's exercise of the venue privilege.

147. The opinion in Reyno stated that the district court had been "fully justified" in giving the plaintiff's choice of venue less weight because the real parties in interest were "foreign." 454 U.S. at 255. The Court reasoned that "[w]hen the home forum has been chosen, it is reasonable to assume that this choice is convenient. When the plaintiff is foreign, however, this assumption is much less reasonable." Id. at 255-56. This reasoning applies, of course, whether the plaintiff is a non-American or an Alaskan suing in Florida. Because Justices Brennan, White, and Stevens dissented from this portion of the opinion, on the ground that it was beyond the question presented for review, only four Justices joined it. See id. at 261-62 (Stevens, J., dissenting) (joined by Brennan, J.); id. at 261 (White, J., concurring in part and dissenting in part). Accordingly, this aspect of the opinion hardly detracts from the actual holding that a plaintiff's desire to shop for favorable law is entitled to little consideration.

148. The argument made in the text does not require acceptance of Currie's state interest view. Many scholars reject his theories and contend that sensible rules of choice of law can be developed. For a survey of the ongoing debate, see Korn, The Choice-of-Law Revolution: A Critique, 83 Colum. L. Rev. 772 (1983); Rosenberg, The Comeback of Choice-of-Law Rules, 81 Colum. L. REv. 946 (1981). The point here is that, absent action by Congress, the federal courts have no body of such rules to apply and must, under Klaxon, defer to the choice-of-law rules of the states in which they sit.

149. See, e.g., Allstate Ins. Co. v. Hague, 449 U.S. 302 (1981) (existence of minimum contacts with forum state justifies interpretation of insurance policy under that state's law); Home Ins. Co. v. Dick, 281 U.S. 397 (1930) (state may not affect rights under insurance contract where parties are 
are likely to have sufficient contacts to satisfy the due process minimum where there is a genuine choice-of-law issue. Although Congress probably has the power to legislate binding choice-of-law rules, ${ }^{100}$ it has not done so. The venue privilege therefore prevails by default; choice-of-law issues in diversity cases are determined by venue provisions, even though venue was originally intended to accomplish entirely different objectives. But the acquired rights theory should not establish an affirmative principle to govern transferred federal claims unless there is a similar vacuum in that situation. There is not, since applicable federal principles do exist.

\section{Federal Principles Favoring Transferee Interpretation After Transfer of Federal Glaims}

Concluding that the core principles of Van Dusen are inapplicable to the choice-of-law problems presented by transfers of federal claim cases does little to identify more appropriate governing principles. ${ }^{151}$ Some sug-

beyond its borders and have no contacts with it). For criticisms of the reasoning in Allstate, see Brilmayer, Legitimate Interests in Multistate Problems: As Between State and Federal Law, 79 Mich. L. Rev. 1315 (1981); Kozyris, Reflections on Allstate: The Lessening of Due Process in Choice of Law, 14 U.C.D. L. REv. 889 (1981). In Headrick, discussed supra pp. 682-83, a good argument could be made that due process would forbid application of the New Mexico statute of limitations.

150. See Baxter, Choice of Law and the Federal System, 16 STaN. L. Rev. 1, 23 (1963) (finding such power in full faith and credit clause); Currie, supra note 38, at 468-69 (finding such power in necessary and proper clause).

151. At the outset, it is worthwhile to reject special federal venue statutes as grounds for deciding the issue in cases based on statutory schemes with such provisions. Several federal statutory schemes, such as the Federal Employers' Liability Act (F.E.L.A.), 45 U.S.C. $\$ 56$ (1976), and the Clayton Antitrust Act, 15 U.S.C. $\$ 22$ (1982), do have their own venue provisions which apply in place of the general venue provisions. One could argue that these federal pronouncements represent decisions by Congress to allow plaintiffs to choose the interpretations of federal law that should govern their cases.

This view is supported by Supreme Court decisions holding that, in the face of such congressional decisions to broaden venue, the federal courts could not dismiss on forum non conveniens grounds if a case were filed in a proper venue. Thus, in United States v. National City Lines, 334 U.S. 573 (1948) (National City Lines $I$ ), the Court held that forum non conveniens could not be applied to an antitrust action. It reasoned that "the choice of venues expressly given to the plaintiff is not to be qualified by any power of a court having venue," $i d$. at 578 , because Congress' purpose in providing broad venue was "to provide broader and more effective relief, both substantively and procedurally, for persons injured by violations of its antitrust policy." Id. at 581 (footnote omitted). It reached a similar conclusion with regard to the F.E.L.A. See Baltimore \& O.R.R. v. Kepner, 314 U.S. 44 (1941); $c f$. Radzanower v. Touche Ross \& Co., 426 U.S. 148 (1976) (narrow venue of National Bank Act, currently codified at 12 U.S.C. $\$ 94$ (1982), permits securities action against bank only in district in which bank is established, notwithstanding broad venue of securities acts).

In view of the Court's reference in National City Lines $I$ to Congress' desire to provide broader relief "substantively," one might argue that the Court believed that Congress approved of forum shopping for favorable interpretations of federal law. The argument is not persuasive. First, the Court held that $\S 1404(a)$ is not similarly limited. In United States v. National City Lines, 337 U.S. 78 (1949) (National City Lines II), decided less than a year after National City Lines I, it upheld transfer of the same case under $\$ 1404(\mathrm{a})$. There is no question that such cases can be transferred pursuant to the multidistrict transfer statute, see supra note 97 (detailing number of transfers of antitrust cases). Due to the special venue provision in antitrust cases, the burden of justifying a $\S 1404$ (a) transfer may be heavier than in other litigation. See Los Angeles Memorial Coliseum Comm'n v. National Football League, 89 F.R.D. 497, 500 (C.D. Cal. 1981). Nevertheless, as with other venue matters, see supra pp. 697-98, once plaintiff's geographical choice is overridden the 
gest that conflicts between the circuits reflect efforts to deal with local problems, ${ }^{162}$ but no federal doctrine prefers the interpretation of the circuit in which the transactions underlying the case occurred. To the contrary, the applicable interpretation is that of the circuit in which the case is filed unless the case is transferred. One must therefore look beyond choice of law to locate an applicable federal principle.

Such a principle stems from the very source of the problem of conflicts between circuits-the system of review established by the Evarts Act. ${ }^{153}$ That system assumes that the courts of appeals are competent to decide questions of federal law correctly and mandates that they do so, subject only to review by the Supreme Court. ${ }^{154}$ This principle of competence undercuts any rule that would require the transferee court to follow another circuit's interpretation of federal law. Neither the legislative history nor the policy of the transfer statutes provides a reason for overriding this principle.

\section{A. The Principle of Competence}

For federal courts, the most significant choice-of-law difference between issues of state law and issues of federal law is that they lack competence to decide the former and are presumptively competent to decide the latter. Swift $v$. Tyson held that federal courts were competent to develop rules of decision for issues of state law. Erie unequivocally rejected that proposition and reserved such determinations for the states. The situation is materially different for issues of federal law, which the federal courts have not only the power but the duty to decide correctly. There is no room in the federal system of review for rote acceptance of the decision of a court outside the chain of direct review. If a federal court simply accepts the interpretation of another circuit without addressing the merits, it is not doing its job.

This principle follows naturally from the structure of appellate review

venue choice should have little impact on choice of law.

Second, as described infra pp. 707-08, the congressional regulatory goal actually cuts in favor of the principle of competence and against emphasizing plaintiff's interest.

152. See supra p. 690.

153. The Circuit Courts of Appeals Act of 1891, supra note 59.

154. A somewhat analogous choice-of-law principle, the supposed propriety of preferring a "better" rule of law, has been suggested as a legitimate factor in selecting rules to decide cases governed by state law. See Leflar, Choice-Influencing Considerations in Conflicts Law, 41 N.Y.U. L. Rev. 267, 295-304 (1966). The notion seems to be that enlightened judges can thereby sidestep anachronistic rules of law by choosing to apply the modern law of another state. Not surprisingly, this concept has been criticized as overly subjective. See E. Scoles \& P. HAY, Conflict of Laws $\S 2.11$ (1982). But with issues of federal law in the federal system, an analogous notion is proper under the principle of competence: The forum circuit's interpretation is always the better law because it is, in the eyes of the forum court, the correct one. 
established by the Evarts Act. Despite early doubts, ${ }^{156}$ the independence of the circuits was quickly established. Thus, in a 1908 case, the Seventh Circuit, after noting that the contentions made by the appellant had all been rejected by the Second Circuit, agreed that appellant "is right in claiming that he is entitled to our independent consideration and judgment." ${ }^{158}$ It then analyzed the issues and reached the same result as the Second Circuit. ${ }^{167}$ The important point, however, is that the Seventh Circuit was not content simply to accept the Second Circuit's decision. It thereby affirmed the rule of competence that has endured to the present.

Appropriately, the principle is dramatically illustrated by an important transfer case, Hoffman v. Blaski. ${ }^{158}$ Plaintiffs there sued in Texas, defendants' residence. The district court granted defendants' motion to transfer to Illinois, plaintiffs' residence, ${ }^{158}$ under section 1404(a). Claiming that section 1404(a) did not authorize the transfer because jurisdiction and venue were not proper in Illinois, plaintiffs petitioned the Fifth Gircuit for a writ of mandamus. That court of appeals denied the petition, squarely holding that the transfer was proper because defendants agreed to waive jurisdictional objections. ${ }^{100}$ After the case was transferred, plaintiffs moved to remand it to Texas on the same grounds that the Fifth Circuit had rejected. The Seventh Circuit agreed with plaintiffs, and granted their petition for a writ of mandamus, concluding that it was not bound by the Fifth Circuit decision: "[W]e think the decision of the Fifth Circuit in this matter is erroneous. Such being the case, we are under no more obligation to follow it as the law of the case than that Gircuit would

155. In Fairfield Floral Co. v. Bradbury, 87 F. 415 (C.C.D. Me. 1898), the court opined that "[m]y own view is that the decisions of the court of appeals in one circuit should ordinarily be followed quite implicitly by the courts in other circuits." Id. at 417; accord Hale v. Hilliker, 109 F. 273 (C.C.N.D.N.Y. 1901), rev'd, 117 F. 220 (2d Cir. 1902), cert. denied, 188 U.S. 739 (1903).

156. Heckendorn v. United States, 162 F. 141, 143 (7th Cir. 1908), cert. denied, 214 U.S. 514 (1909).

157. Id.

158. 363 U.S. 335 (1960).

159. It may initially seem odd that plaintiffs would oppose transfer to their home district, much less go to the effort of petitioning two courts of appeals to vindicate their right to remain in the defendants' home district. But plaintiffs' behavior demonstrates that modification of the federal appellate structure probably will not entirely eliminate forum shopping. Plaintiffs in Hoffinan charged the defendants with violating plaintiffs' patent. The Seventh Circuit had long been regarded as tough on plaintiffs asserting claims under patents, and quick to hold patents invalid. Thus, plaintiffs' efforts to keep the case out of their home district presumably reflected their desire to avoid the Seventh Circuit. As indicated above, see supra pp. 690-91, such perceived differences between circuits will not change if a new court is added to the appellate system. With patents, the matter has been resolved by shifting all appellate jurisdiction in patent cases to the Court of Appeals for the Federal Circuit, see Federal Courts Improvement Act of 1982, Pub. L. No. 97-164, § 127, 96 Stat. 25, 37-39 (1982), but relying on specialized courts with nationwide authority is not an attractive solution to the general problem of intercircuit conflicts.

160. Ex parte Blaski, 245 F.2d 737, 738 (5th Cir.), cert. denied sub nom. Blaski v. Davidson, 355 U.S. 872 (1957). 
be to follow what it considers an erroneous decision by this court."161 The Supreme Court granted certiorari and affirmed the Seventh Circuit. ${ }^{182}$ Whatever the merit of the Seventh Circuit's disregard of the law of the case, ${ }^{168}$ Hoffman $v$. Blaski makes clear that one circuit need not follow a decision of another circuit that it regards as erroneous. ${ }^{184}$ Accordingly, even those circuits that stress the need for uniformity in federal law say that they will not follow erroneous decisions of other circuits. ${ }^{165}$

The principle of competence applies even to the decision of federal issues by state courts. ${ }^{168}$ Indeed, until 1875 , state courts were the only courts with general jurisdiction over federal claims, ${ }^{167}$ and the federal

161. Blaski v. Hoffman, 260 F.2d 317, 322 (7th Cir. 1958) (citation omitted), aff'd, 363 U.S. 335 (1960).

162. 363 U.S. 335 (1960).

163. Justice Frankfurter dissented on the ground that the Seventh Circuit could not reconsider the issue decided by the Fifth Circuit. See 363 U.S. at 345, 347-48 (Frankfurter, J., dissenting); see also Hayman Cash Register Co. v. Sarokin, 669 F.2d 162, 170 (3d Cir. 1982) (erroneous to retransfer, despite fact that statute did not authorize transfer in first place, because issue was already decided by transferor court and thus was law of case). But Justice Frankfurter did not contend that, absent law of the case, the Seventh Circuit would be obligated to follow the Fifth Circuit interpretation.

164. For a recent example, see Newsweek v. United States Postal Serv., 663 F.2d 1186, 1196 (2d Cir. 1981) (Second Circuit rejects District of Columbia Circuit's interpretation of 39 U.S.C. $\S 3622(b)$ (1976)), aff'd sub nom. National Ass'n of Greeting Card Publishers v. United States Postal Serv., 103 S. Ct. 2717 (1983).

165. See North Am. Life \& Casualty Co. v. Commissioner, 533 F.2d 1046, 1051 (8th Cir. 1976) (in area of taxation, decision of other circuits "should be followed unless they are demonstrably erroneous or there appear cogent reasons for rejecting them") (citations omitted).

166. The rule of competence applies as well to federal court determinations of questions of state law. See Plant v. Blazer Fin. Serv., 598 F.2d 1357, 1363 (5th Cir. 1979) ("diversity jurisdiction presumes federal courts' competence to decide state law issues"). Federal courts must interpret the state law themselves when there is no definitive interpretation from the supreme court of the state. When interpreting state law, federal courts usually do not defer to one another. Waters v. American Auto Ins. Co., 363 F.2d 684, 689 (D.C. Cir. 1966). Some courts will defer to an interpretation of state law by a district judge who sits in that state, on the theory that he is more familiar with it. See C. WRIGHT, THE LAW OF FEDERAL CourTs § 58, at 375-76 (4th ed. 1983). Otherwise it is the responsibility of each federal court to make its own interpretation of uncertain state law rather than following the interpretation of another federal court.

For a break with this approach, see Factors Etc., Inc. v. Pro Arts, Inc., 652 F.2d 278 (2d Cir. 1981), cert. denied, 456 U.S. 927 (1982), in which a sharply divided panel of the Second Circuit decided to defer to a decision of the Sixth Gircuit on an unsettled question of Tennessee law because Tennessee is in the Sixth Circuit. In dissent, Judge Mansfield chastised the majority for "blindly following" the Sixth Circuit, 652 F.2d at 284, asserting that the Second Gircuit is "as fully qualified effectively to 'declare' Tennessee law in such fashion as our sister circuit" and that it should therefore "so hold rather than retreat behind unsupportable deferential niceties." Id. at 286. For criticism of the decision, see Note, Circuit Court of Appeals Must Accord Conclusive Deference to Another Circuit's Determination of the Law of a State Within the Other Circuit: Factors Etc., Inc. v. Pro Arts, Inc., 67 CORNELL. L. REv. 415 (1982). The existence of a debate even as to interpretation of state law shows that the principle of competence is firmly entrenched.

167. In the Judiciary Act of 1875 , ch. 137, 18 Stat. 470 (1875), Congress expanded the jurisdiction of the lower federal courts to almost the full extent of the constitutional authorization, limiting it only with provisions such as amount in controversy. Until then, the federal courts had jurisdiction only over diversity cases and a few limited headings of federal question matters-admiralty, patent, and bankruptcy. See F. FRANKFURTER \& J. LANDIS, supra note 57, at 65-69; Stolz, Federal Review of State Court Decisions of Federal Questions: The Need for Additional Appellate Capacily, 64 CALIF. L. REv. 943, 949 (1976) (referring to "enormous area in which state courts were thought fully competent to articulate federal law"). 
courts have never had jurisdiction over cases involving anticipated federal defenses to state law claims in the absence of diversity of citizenship. ${ }^{168}$ Today, except for claims within exclusive federal jurisdiction, the state courts exercise concurrent jurisdiction over federal claims and must therefore frequently decide issues of federal law. ${ }^{189}$ Subject to review by the Supreme Court, ${ }^{170}$ they are competent to do so, and there is accordingly no requirement that they accept the interpretation of any lower federal court. ${ }^{171}$ In fact, a series of recent Supreme Court decisions emphasizes the right and responsibilty of state courts to decide federal issues without interference from the lower federal courts. ${ }^{172}$

As Hoffman v. Blaski illustrates, ${ }^{173}$ this principle of competence applies as forcefully to a transferred case as to any other case involving an issue on which the circuits conflict. After transfer, the transferee court has the same right and duty to decide the transferred federal claim on its own as it has in every other case. This proposition found expression in a number of pre-Van Dusen cases. For example, in Ackert v. Bryan, ${ }^{174}$ the Second

168. Louisville \& N.R.R. v. Mottley, 211 U.S. 149 (1908). At times, the Supreme Court has chafed at these limitations, particularly where they interfere with the uniformity of national law. See Franchise Tax Bd. v. Construction Laborers Vacation Trust, 103 S. Ct. 2841, 2843 (1983) ("The issue is an important one, which affects thousands of federally regulated trusts and all non-federal tax collection systems, and it must eventually receive a definitive, uniform resolution. Nevertheless, for reasons involving perhaps more history than logic, we hold that the lower federal courts had no jurisdiction to decide the question in the case before us . ....").

169. See Redish \& Muench, Adjudication of Federal Causes of Action in State Courl, $75 \mathrm{MrcH}$. L. REV. 311 (1976).

170. 28 U.S.C. $§ 1257$ (1976).

171. As Professor Stolz has argued, the absence of scrutiny by any lower federal court argues in favor of creation of a national court of appeals to review state court decisions in federal question cases. Stolz, supra note 167 , at 964-74.

172. Because civil cases raising federal claims can generally be removed to federal court, see supra p. 696, the cases in which the Court has articulated its confidence in state court disposition of federal issues, not surprisingly, have involved state criminal proceedings. Beginning with Younger v. Harris, 401 U.S. 37 (1971), the Court has on several occasions overturned federal court orders that interdicted state court criminal proceedings claimed to infringe the federal constitutional rights of the state court defendants. As the Court explained, Younger was intended to "permit state courts to try state cases free from interference by federal courts." Id. at 43. In Stone v. Powell, 428 U.S. 465 (1976), the Court held that a federal court could not issue a writ of habeas corpus based on a claim that evidence used in a state criminal proceeding was seized in violation of the Fourth Amendment if the state court had accorded a full and fair opportunity to litigate the claim of illegal seizure. It noted that "[s]tate courts, like federal courts, have a constitutional obligation to safeguard personal liberties and to uphold federal law." Id. at 494 n.35 (citing Martin v. Hunter's Lessee, 14 U.S. (1 Wheat.) 304, 341-44 (1816)). In Allen v. McCurry, 449 U.S. 90 (1980), the Court took another step toward insulating state court criminal judgments against collateral attack in federal court by holding that, in an action for damages under 42 U.S.C. \$ 1983 (1976), collateral estoppel could foreclose relitigation of the constitutionality of seizure of evidence. It rejected the argument that by enacting $\$ 1983$ Congress intended to abrogate the general rule that state court determinations should be accorded full faith and credit in federal court. Id. at 105. To the contrary, it pointed to "this Court's emphatic reaffirmation in [Stone v. Powell] of the constitutional obligation of the state courts to uphold federal law, and its expression of confidence in their ability to do so." Id.

173. See supra pp. 703-04.

174. 299 F.2d 65 (2d Cir. 1962). 
Circuit was asked to overturn an order transferring a case to the District of Minnesota in the Eighth Circuit. Plaintiff, a stockholder asserting a claim under the Investment Company Act of $1940,{ }^{175}$ argued that transfer was improper because the Eighth Circuit did not allow a stockholder to sue under that statute, while the Second Circuit did. Since transfer would therefore be tantamount to dismissal of his claim, plaintiff contended it was unauthorized because Minnesota was not a district in which the action could have been brought, as required by section 1404(a). ${ }^{178}$ The Second Circuit accepted arguendo that the law of the Eighth Circuit was as plaintiff pictured it, ${ }^{177}$ but remained unmoved. It assumed that the transferee court would apply the Eighth Circuit interpretation but held that any difference in outcome did not present "a true conflict of laws problem, ${ }^{, 178}$ but rather a matter to be resolved by the Supreme Court. ${ }^{178}$ Not even plaintiff suggested that the federal court in Minnesota should apply the Second Circuit interpretation after transfer.

More significantly, in H.L. Green Co. v. MacMahon, ${ }^{180}$ a case the Supreme Court cited and quoted in Van Dusen, ${ }^{\mathbf{1 8 1}}$ the Second Circuit confirmed in dictum that litigants have no vested right in a particular interpretation of federal law:

A plaintiff may not resist the transfer of his action to another district court on the ground that the transferee court will or may interpret federal law in a manner less favorable to him .... The federal courts comprise a single system applying a single body of law, and no litigant has a right to have the interpretation of one federal court rather than that of another determine his case. ${ }^{182}$

The assumption that each federal court is competent to decide federal questions is therefore inconsistent with preserving the selection of a given circuit's interpretation, just as it is inconsistent with an attempt to select a particular federal judge. ${ }^{183}$ In each instance, the system abhors efforts to

175. 15 U.S.C. $\S \S 80 a-1$ to -64 (1982).

176. 299 F.2d at 69 .

177. The court also indicated that it was not fully persuaded plaintiff was right about the Eighth Gircuit view. See id.

178. Id. (citing E. Cheatham, H. Goodrich, E. Griswold \& W. Reese, Gases and MaterIALS ON CoNflict OF LAWS 585-86 (4th ed. 1957)).

179. 299 F.2d at 70 .

180. 312 F.2d 650 (2d Cir. 1962), cert. denied, 372 U.S. 928 (1963).

181. See Van Dusen v. Barrack, 376 U.S. 612, 632-33 (1964).

182. 312 F.2d at 652; accord Clayton v. Warlick, 232 F.2d 699, 706 (4th Cir. 1956).

183. Within a given district, lawyers may be tempted to try to have a case assigned to a judge whom they view as receptive to their cause. Cf. J. Goulden, The Benchwarmers 11-20, 114-57 (1974) (describing disparities in quality among federal judges). Nevertheless, such efforts are properly spurned on the ground that all judges are competent to decide cases. See Shopping for a Judge?, Nat'l L.J., Apr. 11, 1983, at 2, col. 2 (describing disciplinary action against lawyer for apparent judge 
undermine the authority of the assigned court to decide the case correctly on the merits.

Emphasizing the competence of federal courts rather than the plaintiff's interest in the most favorable interpretation of federal law also accords with the objectives of many federal statutes that Congress designed not only to provide compensation but also to achieve federal regulatory goals. For example, private claims for violation of the antitrust laws are meant to aid enforcement of those statutes, ${ }^{\mathbf{1 8 4}}$ and the private remedies provisions of the civil rights acts similarly were designed to assist efforts against racial discrimination. ${ }^{185}$ The point is especially important where the courts have themselves implied a right to sue for damages in order to further congressional regulatory objectives. ${ }^{186}$ In such circumstances, compensation is not the primary purpose of the private claim. In view of the regulatory objectives of many federal claims, it is inappropriate to give substantial weight to plaintiffs' attempts to capture a certain interpretation of federal law. ${ }^{187}$

shopping in Central District of California); see also Cheeseman v. Carey, 485 F. Supp. 203 (S.D.N.Y.), remanded, 623 F.2d 1387 (2d Cir. 1980), where the court denied defendants' motion to transfer to the Northern District of New York, but observed:

Had plaintiffs selected this forum to avoid specific precedents in the Northern District, the case for a transfer would have been far stronger. Just as this district's local rules are designed to prevent shopping for individual judges-and thereby for the application of some anticipated view of the law-efforts to select one district to avoid or to obtain specific rulings of another district court should be disfavored and discouraged.

Id. at 215; accord Semmes Motors v. Ford Motor Co., 429 F.2d 1197, 1203 (2d Cir. 1970); In re Texas Gulf Sulphur Sec. Litig., 344 F. Supp. 1398, 1400 (J.P.M.D.L. 1972); cf. Deposit Guar. Nat'l Bank v. Roper, 445 U.S. 326, 339-40 (1980) ("Permitting appeal of the district court's certification ruling . . . also minimizes problems raised by 'forum shopping' by putative class representatives attempting to locate a judge perceived as sympathetic to class actions.").

184. The courts have repeatedly emphasized the important role of private plaintiffs in enforcing the antitrust laws. See, e.g., Bruce's Juices, Inc. v. American Can Co., 330 U.S. 743, 751-52 (1947); Javelin Corp. v. Uniroyal, Inc., 546 F.2d 276, 280 (9th Cir. 1976), cert. denied, 431 U.S. 938 (1977).

185. See Allen v. McCurry, 449 U.S. 90, 98 (1980) (main goal "to override the corrupting influence of the Ku Klux Klan"); Adickes v. S.H. Kress \& Co., 398 U.S. 144, 234 (1970) (Brennan, J., concurring in part and dissenting in part) (purpose of 42 U.S.C. $\S 1983$ (1976) "to stamp out widespread violations of constitutional rights at virtually any cost"); Gressman, The Unhappy History of Civil Rights Legislation, 50 Mrch. L. REv. 1323, 1334 (1952) (creation of private remedies intended to protect against Klan-inspired lynchings and mob violence).

186. See J.I. Case Co. v. Borak, 377 U.S. 426 (1964), in which the Court upheld implication of a private remedy for alleged misuse of proxies in violation of $\S 14(\mathrm{a})$ of the Securities Exchange Act of 1934,15 U.S.C. $\$ 78 n(a)$ (1982). The Court reasoned that "[p]rivate enforcement of the proxy rules provides a necessary supplement to [Securities and Exchange] Commission action . . . [T] bility of civil damages or injunctive relief serves as a most effective weapon in the enforcement of the proxy requirements." 377 U.S. at 432 . Since Borak, of course, the Court has cut back on the implication of private remedies. See Touche Ross \& Co. v. Redington, 442 U.S. 560 (1979). The point here is that the principal objective for implying remedies, when that is allowed, is to further a congressional regulatory goal, not to provide private compensation.

187. Plaintiffs could argue that the congressional policy would always be furthered by rules favoring plaintiffs, but in reality regulation through private litigation is a two-edged sword. Indeed, the Antitrust Division of the Department of Justice is sufficiently concerned about overbroad interpretation of the antitrust laws in private litigation that it has participated in certain private cases to oppose positions taken by plaintiffs. William Baxter, Assistant Attorney General and head of the Antitrust 
The outer boundaries of the principle of competence are illustrated by the recurrent problems in applying statutes of limitations to transferred federal claims. Many federal claims, particularly those implied by the courts, lack congressionally set limitations periods. Arguably the federal courts could themselves fashion limitations periods, but they have steadfastly declined to do so on the ground that such an effort would involve inappropriate judicial legislation. ${ }^{188}$ Put differently, the problem is beyond the competence of federal courts. Accordingly, the Supreme Court early directed that a federal court should apply the limitations period employed by the state in which it sits for the most closely analogous state law claim. ${ }^{189}$ This approach, of course, has caused great disparities in limitations periods applied to certain federal claims ${ }^{190}$ and has raised interesting choice-of-law questions after transfer of such claims. In H.L. Green Co. $v$. MacMahon, ${ }^{191}$ the Second Circuit decided that a transfer should not alter the limitations period that plaintiff had acquired by the exercise of his venue privilege, a conclusion implicitly adopted by the Supreme Court in its reliance on Green in Van Dusen. ${ }^{102}$ This conclusion is not inconsistent with the principle that federal courts are competent to decide issues of federal law, since federal courts are not competent to create limitations periods where Congress has failed to specify them. By default, the matter therefore turns on plaintiff's choice of forum. Many of the cases holding

Division of the Department of Justice, has announced that the Division will, in appropriate cases, support arguments made by defendants in antitrust cases. Generally this effort is by amicus brief. See Department of Justice Authorization for Fiscal Year 1984, Subcomm. on Monopolies \& Commercial Law of the Comm. of the Judiciary, 98th Cong., 1st Sess. 18-20 (1983). For a case in which the Division has so acted, see Spray-Rite Serv. Corp. v. Monsanto Co., 684 F.2d 1226 (7th Cir. 1982), cert. granted, 103 S. Ct. 1249 (1983), in which the Division is urging that resale price maintenance should not be treated as a per se violation of antitrust law, but judged instead under the rule of reason. See Antitrust Revolution Slows, Nat'l L.J., July 25, 1983, at 1, col. 1. For a list of the cases in which the Division has submitted amicus briefs, see 44 AnTITrust \& Trade Reg. REP. (BNA) No. 1106, at 612-14 (March 17, 1983).

188. Thus, in UAW v. Hoosier Cardinal Corp., 383 U.S. 696 (1966), the Court was asked to establish a uniform limitations period for claims under $\$ 301$ of the Labor Management Relations Act, currently codified at 29 U.S.C. $\$ 185$ (1976), which did not specify a period of limitations. The Court characterized the request as seeking a "drastic sort of judicial legislation," 383 U.S. at 703, and refused to indulge in "so bald a form of judicial innovation." Id. at 701.

189. The first such case was M'Cluny v. Silliman, 28 U.S. (3 Pet.) 270 (1830). For discussions of the borrowing practice, see Special Project, Time Bars in Specialized Federal Common Lau: Federal Rights of Action and State Statutes of Limitations, 65 CoRNELL L. REv. 1011, 1043-46 (1980); Note, Federal Statutes Without Limitations Provisions, 53 Colum. L. Rev. 68 (1953).

Arguably the federal courts should develop some choice-of-law principles to determine which state's limitations period should apply. Thus, where the claim arose in State $X$, it might be appropriate to apply its limitations period although the suit was filed in federal court in State $Y$. The argument made in the text does not address this question, but focuses only on the question whether a transfer should change the limitations period.

190. For example, in actions under $\S 10(\mathrm{~b})$ of the Securities Exchange Act of 1934, 15 U.S.C. $\S$ $78 \mathrm{j}(\mathrm{b})$ (1982), limitations periods have varied from one to ten years. Ruder \& Cross, Limitations on Cizil Liability Under Rule 10b-5, 1972 Duke L.J. 1125, 1144.

191. 312 F.2d 650 (2d Cir. 1962), cert. denied, 372 U.S. 928 (1963).

192. See 376 U.S. at 632-33. 
that the law of the transferor forum applies are hence correct because these cases actually only consider the statute of limitations question. ${ }^{193}$ At least one court has explicitly recognized that determination of the limitations period is different from other issues, which the transferee court is of course competent to decide. ${ }^{194}$ But there remains the problem of selecting the "analogous" state limitations period. On this federal question, some transferee courts make their own analysis, ${ }^{195}$ while others follow the analysis of the transferor circuit. ${ }^{108}$ Given the principle of competence, the transferee court should decide for itself.

\section{B. Interpretation of the Transfer Statutes}

Ultimately Van Dusen is a statutory construction case; the first sentence of the opinion announces that " $t]$ his case involves the construction and application of $\S 1404(a) \ldots . .3197$ Given the assumption that applying Van Dusen to transfers of federal claims violates the principle of competence, there remains the question whether the transfer statutes require that result.

This question is difficult to answer with absolute certainty. Since the principle of competence is a starting point, a substantial showing should be required to justify overriding it, and there appears to be no reason to do so. The legislative history of the transfer statutes provides little guidance. One could argue that permitting a change of law might frustrate the purposes of the transfer statutes by deterring courts from transferring, but the risk that courts would decline to transfer on this ground seems slight. More significant, therefore, are the numerous difficulties that would be caused by requiring the application of the transferor circuit's interpreta-

193. E.g., Berry Petroleum Co. v. Adams \& Peck, 518 F.2d 402, 408-09 (2d Cir. 1975); Sargent v. Genesco, Inc., 492 F.2d 750, 758 (5th Cir. 1974); Railing v. UMW, 429 F.2d 780, 781 (4th Cir. 1970), v'acated, 401 U.S. 486 (1971); Thorn v. New York City Dep't of Social Servs., 523 F. Supp. 1193, 1197 (S.D.N.Y. 1981); Campbell v. Upjohn Co., 498 F. Supp. 722, 726 (W.D. Mich. 1980), aff'd, 676 F.2d 1122 (6th Cir. 1982); In re Clinton Oil Co. Sec. Litig., [1977-1978 Transfer Binder] Fed. Sec. L. REP. (CCH) If 96,015 (D. Kan. Mar. 18, 1977); Corey v. Bache \& Co., 355 F. Supp. 1123, 1125 (S.D.W. Va. 1973).

As a consequence, Van Dusen will have some enduring effect on transferred federal claims until a federal principle for selection of a limitations period is developed. See supra note 189 . But it is worth noting that Van Dusen should be inapplicable to federal issues in diversity cases, which the federal courts are competent to decide. For example, in a libel action the transferee court is competent to decide any First Amendment defense without deferring to the interpretation of the transferor federal court or the courts of the state in which the transferor court sits. Thus, the basic principle of competence endures.

194. Roth v. Bank of the Commonwealth, [1981-1982 Transfer Binder] FED. SEC. L. REP. (CCH) 1 98,267 , at 91,712 (W.D.N.Y. Aug. 17, 1981).

195. Corey v. Bache \& Co., 355 F. Supp. 1123, 1125-26 (S.D.W. Va. 1973).

196. E.g., Berry Petroleum Co. v. Adams \& Peck, 518 F.2d 402, 408 (2d Cir. 1975); In re Clinton Oil Co. Sec. Litig., [1977-1978 Transfer Binder] Fed. SEC. L. Rep. (CCH) II 96,015 (D. Kan. Mar. 18, 1977).

197. 376 U.S. at 613. 
tion. Accordingly, the statutes should not be interpreted as rejecting the principle of competence.

\section{Legislative History}

The legislative history of section 1404(a) says little about choice of law. Indeed, the drafters may never have considered which forum's law should apply to transferred cases. ${ }^{108}$ In Van Dusen, the Supreme Court found the legislative history inconclusive and therefore relied on the assumption that Congress did not intend to alter the principle of venue privilege in diversity cases. When section 1404(a) was enacted, the principle of competence was also well established, however, and there is similarly no basis in the legislative history for concluding that Congress meant to depart from it.

The legislative history of the multidistrict litigation statute does provide an argument for applying transferor law to transferred federal claims, but the argument carries little weight. In hearings before the Senate subcommittee responsible for the bill that eventually became law, two witnesses who had been involved in the handling of the electrical equipment price fixing cases, ${ }^{198}$ Dean Phil Neal and Judge William Becker, both stated that Van Dusen would apply to choice-of-law issues under the new statute. ${ }^{200}$ Since their experience related to federal claims for violation of the antitrust laws, these comments may provide a basis for retaining transferor interpretation after multidistrict transfer of federal claims. But Van

198. It has been reported that Professor Moore, who proposed $\S 1404(\mathrm{a})$, stated in 1964 that the drafters never considered the choice-of-law problems it would create. Note, Choice of Law Afler Transfer of Venue, 75 Yale L.J. 90, 94 \& n.24 (1965). Before the statute was enacted, however, Professor Braucher raised the choice-of-law problem in a law review article. Braucher, The Inconvenient Federal Forum, 60 HaRv. L. Rev. 908, 936 (1947).

199. The many federal suits filed in the wake of the price fixing convictions in the electrical equipment industry, approximately 25,000 claims in nearly 2,000 suits, were administered by a Coordinating Committee for Multiple Litigation in the United States District Courts, which was established by Chief Justice Warren for that purpose. Dean Neal was Executive Secretary of the Committee, and Judge Becker was a member of it.

200. Dean Neal testified as follows in response to a question from Senator Tydings, sponsor of the legislation:

Senator Tydings. Dean Neal, there would be a variety of questions of law involving substantive as well as procedural rights that would have to be decided by the transferee judge, such as capacity to sue, limitations and other bars to action, privileged communications, scope of discovery, and so forth. Are questions of choice of law sufficiently settled so that we do not have to spell it out in the legislation here, or do we need statutory guidelines?

Dean NeAl. I think the answer has been indicated quite clearly by the Supreme Court in the Van Dusen case of a year or two ago, in which the court held that in cases transferred under section 1404(a) the applicable law would be the law that would have been applied had the case remained in the transferor district. I see no reason to suppose that that rule would not govern under section 1407 as well.

Multidistrict Litigation: Hearings on S. 3815 Before the Subcomm. on Improtements in Judicial Machinery of the Senate Comm. on the Judiciary, 89th Cong., 2d Sess. 13 (1966) (statement of Dean Neal) [hereinafter cited as Hearings: Multidistrict Litigation Bill]. Judge Becker testified that he agreed with Dean Neal. Id. at 25 (statement of Judge Becker). 
Dusen itself was carefully limited to questions of state law, ${ }^{201}$ and the testimony of Dean Neal and Judge Becker seems to mean only that Van Dusen would apply to state law issues in cases transferred under the new statute. Since many diversity cases would be subject to transfer under the multidistrict statute, the testimony can best be interpreted as applying to such situations.

The contemplated functioning of the multidistrict transfer provision might support an argument that Congress intended transfers to effect no change in substantive law. Unlike section 1404(a), the new statute authorized transfer only for pretrial purposes. This limitation arguably shows that Congress wanted to guard against changes in applicable interpretation. Some commentators have in fact contended that the courts subsequently expanded the powers of the transferee courts to decide the merits of transferred cases beyond Congress' original intention. ${ }^{202}$ But, in fact, transferee courts have usually decided transferred cases, ${ }^{203}$ so the supposed restriction of their power to pretrial matters is hardly a basis for preserving transferor interpretation of federal law. As with section 1404(a), there is no helpful guidance in the legislative history of the multidistrict statute.

\section{The Risk of Deterring Transfers}

In Van Dusen, the Court reasoned that applying the law of the transferee state in diversity cases would frustrate the remedial purposes of section 1404(a) because courts would then be reluctant to grant transfers for fear of prejudicing plaintiffs' cases. ${ }^{204}$ Obviously the prospect did not deter the district judge in Van Dusen ${ }^{205}$ but the risk that others would be deterred might still justify interpreting the transfer statutes to preserve plaintiff's original choice of law.

Unfortunately, it is difficult to evaluate the risk that courts would ultimately be deterred from transferring by application of the transferee's law to transferred federal claims. One decision by the Judicial Panel on Multidistrict Litigation suggests that it might be. In In re Plumbing Fixtures Litigation, ${ }^{208}$ a plaintiff in a tag-along case resisted transfer on the ground that, as an indirect purchaser, it would be prejudiced by a transfer to the Eastern District of Pennsylvania, which had held that indirect purchasers

201. Sep 376 U.S. at $625-26,630,633,635,639$.

202. See Note, Experience of Transferee Courts, supra note 29, at 595-96, 602-03.

203. Sep supra p. 681.

204. Sep 376 U.S. at 629-30.

205. The district judge's citation of Headrick v. Atchison, T. \& S.F. Ry., 182 F.2d 305 (10th Cir. 1950), suggests that he may have believed transferor law would apply. See Popkin v. Eastern Air Lines, 204 F. Supp. 426, 433 (E.D. Pa.), racated sub nom. Barrack v. Van Dusen, 309 F.2d 953 (3d Cir. 1962), rev'd, 376 U.S. 612 (1964).

206. 342 F. Supp. 756 (J.P.M.D.L. 1972). 
lacked standing to sue for price fixing. The Supreme Court had not yet resolved this issue. Without citing the legislative history, the Panel rejected plaintiff's argument on the ground that it was "clear" that Van Dusen required application of transferor law. ${ }^{207}$ There is thus at least an implication that the Panel would otherwise have had second thoughts about transferring the case. Certainly the Third Circuit's holding in Piper Aircraft Co. v. Reyno - that dismissal on forum non conveniens grounds is never allowed where it will result in an adverse change of law ${ }^{208}$ - suggests that there is a similar risk with motions under section 1404(a).

The risk nevertheless does not appear great. In large part, the Third Circuit's holding in Reyno was based on its interpretation of Van Dusen. ${ }^{209}$ The Supreme Court's reversal in Reyno made it clear that such solicitude for plaintiffs' forum shopping was unwarranted. Moreover, plaintiffs' desire to capture a favorable interpretation of federal law or courts' solicitude for that desire hardly seems to counterbalance the principle of competence. In fact, the pre-Van Dusen cases concluded that a potential change in interpretation of federal law was irrelevant to a transfer motion because a plaintiff has no right to select among interpretations. ${ }^{\mathbf{2 1 0}}$ Finally, the Multidistrict Panel's inclination to stress matters of judicial economy suggests that it will not expend judicial resources merely to preserve the plaintiff's desired interpretation of federal law. ${ }^{211}$ Accordingly, while the risk of deterring transfers appears substantial in the abstract, in reality it seems to be of little importance in determining whether the transfer statutes override the principle of competence. ${ }^{\mathbf{2 1 2}}$

\section{Id. at 758 .}

208. Reyno v. Piper Aircraft Co., 630 F.2d 149 (3d Gir. 1980), rev'd, 454 U.S. 235 (1981). As indicated supra note 137, it may be that the Supreme Court overstated the Third Circuit's adherence to this doctrine.

209. See 630 F.2d at 163-64 (relying on DeMateos v. Texaco, Inc., 562 F.2d 895 (3d Cir. 1977), cert. denied, 435 U.S. 904 (1978)). In DeMateos, the Third Gircuit found Van Dusen to compel its holding. 562 F.2d at 899.

210. See supra p. 706. In Ackert v. Bryan, 299 F.2d 65 (2d Cir. 1962), for example, the court transferred despite plaintiff's argument that the transfer would be tantamount to a dismissal. See supra p. 706.

211. In In re Texas Gulf Sulphur Sec. Litig., 344 F. Supp. 1398 (J.P.M.D.L. 1972), the Panel evinced little sympathy for such concerns: "[T] he prospect of an unfavorable ruling by the transferee court or the possibility that another district judge may be more favorably disposed to a litigant's contentions are clearly not factors considered by the Panel in determining whether transfer for coordinated or consolidated pretrial proceedings is appropriate." Id. at 1400 (citations omitted).

212. Bul see 15 Federal Practice \& Procedure, supra note 14, § 3854, at 298 (arguing that transfer would not be "in the interests of justice" if it resulted in adverse change in interpretation of federal law). 


\section{Difficulties Caused by Applying Transferor Interpretation}

Applying Van Dusen to federal claims can cause three types of difficulties: problems in ascertaining foreign law, uncertainties about the breadth of the required borrowing from the transferor forum, and complications in consolidated cases. These difficulties could significantly increase the burdens upon federal courts. The transfer statutes were enacted to reduce such burdens by making more efficient use of the unitary federal system, and they should be interpreted accordingly.

\section{a. Difficulty in Ascertaining Foreign Interpretation}

Erie requires federal courts, upon deciding that state law governs a given issue, to determine what the controlling state law is. Often this task requires federal courts to resolve extremely difficult issues without precise guidance from the state cases. ${ }^{213}$ The law of forum non conveniens was intended in part to extricate federal courts from such predicaments. Thus, when the Supreme Court upheld the common law power of a federal court to dismiss on forum non conveniens grounds, it noted that such dismissal was permissible in part to save the court the trouble of having to "untangle problems . . . in law foreign to itself."214 Similarly, Piper Aircraft Co. v. Reyno confirmed that dismissal was appropriate to avoid "complex exercises in comparative law."215 Applying Van Dusen to transfers of federal claims, however, would create equally severe problems of interpretation.

To put the matter in perspective, consider the difficulty that district courts often encounter in deciding what their own courts of appeals would hold on important issues. Particularly where the circuit is large, various panels may take different approaches to the same issue of federal law, leaving the district courts in a muddle pending an en banc resolution. This problem is serious enough to cause some to favor splitting up the larger circuits. Since issues on which the circuits conflict are often inherently difficult, any determination by a lower court on such issues prior to an en banc resolution is a challenging task.

This difficulty would be compounded were the transferee judge required to divine the attitude of another circuit on such questions. The absence of a recognized conflict would not mean that he could assume that the transferor circuit would decide a given issue in the same way as his

213. For a review of the "rules" that guide a federal court in this effort, see C. WrIGHr, supra note $166, \S 58$. For an example of the difficulties that this analysis can impose on a federal court, see McKenna v. Ortho Pharmaceutical Corp., 622 F.2d 657 (3d Cir.), cert. denied, 449 U.S. 976 (1980).

214. Gulf Oil Corp. v. Gilbert, 330 U.S. 501, 509 (1947).

215. 454 U.S. at 251. This concern is more common with non-American law, but it may apply as well to domestic issues. 
own circuit. ${ }^{218}$ The transferee judge would need to examine the law of the transferor circuit in every case, and to guess what another circuit would say about the issue presented. Unlike a district judge in that circuit, the transferee judge could not even hope that an appeal would give him specific guidance. Instead, since appeal would be to the transferee circuit, the appellate court would face the same task as the transferee district judge.

The added burden of ascertaining foreign interpretations is not imaginary. ${ }^{217}$ In this era of hyperlexis, ${ }^{218}$ federal district courts have enough difficulty rendering decisions on federal issues that are consistent with the views of the courts that review those decisions; it would be unnecessarily burdensome to require them to decide how other circuits would resolve those issues. The principle of competence does not assume that transferee judges can accomplish this task; neither should the transfer statutes.

\section{b. Substance v. Procedure-How Broad the Reference?}

Even if required to apply the interpretation of the transferor circuit, the transferee court could still apply its own rules with respect to some matters. Van Dusen confirmed that after transfer of diversity cases the plaintiff retains only that transferor law which would "significantly affect the outcome of the case."219 The transferee court is free to apply its own "rules governing the conduct and dispatch of cases."220 On its face, this statement appears to adopt a rule resembling one test used under Erie to

216. Indeed, the potential for conflicting decisions, even if unrealized, prevents federal court decisions from having binding national effect, and therefore is a factor which many argue supports reform of the federal appellate system. E.g., Hruska Commission, supra note 1, at 219; Meador, A Comment on the Chief Justice's Proposals, 69 A.B.A. J. 448, 449 (1983). To the degree one seeks to preserve the attitude of the transferor circuit, see supra p. 691, the task becomes almost metaphysical.

217. See In re Haven Indus., 462 F. Supp. 172 (S.D.N.Y. 1978). The issue there was whether in pari delicto should operate as a defense to an action by a "tippee" against a "tipper" where a violation of $\S 10(b)$ of the 1934 Securities Exchange Act occurred. Since the case was transferred from the District of Massachusetts, the judge in New York concluded that he had to apply the law of the First Gircuit. Although two other circuits and Judge Weinfeld of the Southern District of New York had decided the issue, neither the First Circuit nor the District of Massachusetts had done so. Faced with conflicting interpretations, the transferee judge noted, "this court's difficult task is to determine what these courts would rule were they to confront the issue." Id. at 179. The court then attempted to do so. The legal analysis was difficult enough without introducing the need for telepathy.

218. See Manning, Hyperlexis: Our National Disease, 71 Nw. U.L. Rev. 767 (1977) (describing "the pathological condition caused by an overactive law-making gland" in America as "a heartworm that has a literally fatal potential for the body politic of this country").

219. 376 U.S. at 639 n.40.

220. Id. In Decker v. Massey-Ferguson Ltd., 29 Fed. R. Serv. $2 d 239$ (S.D.N.Y. 1979), aff'd in part and rev'd in part, 681 F.2d 111 (2d Cir. 1982), the court applied this distinction to a transferred federal claim. Defendant moved to dismiss on the ground that plaintiff's complaint for securities fraud failed to satisfy Fed. R. Civ. P. 9(b), which requires particularity in pleading fraud. Plaintiff argued that the Third Circuit interpretation of Rule 9(b) should be followed because the case was originally filed in the Eastern District of Pennsylvania and transferred to New York. The court rejected plaintiff's argument as "specious," reasoning that "rules governing pleadings, like the one involved here clearly are procedural and not substantive." Id. at 240 n.2. 
determine which matters in diversity cases must be decided by state law-the "outcome-determinative" analysis of Guaranty Trust Co. v. York. ${ }^{221}$ In transferred diversity cases, the Guaranty Trust standard, though difficult to apply, is logical because it permits the transferee court to apply its own interpretation to the issues governed by federal law. ${ }^{222}$

The same approach is of doubtful utility in cases where federal claims are transferred. Drawing the line between matters of substance and procedure could become difficult. Arguably, an outcome-determinative analysis would require application of the transferee court's interpretation of some or all of the Federal Rules of Civil Procedure. Although Hanna v. Plumer held that the Federal Rules of Civil Procedure should be applied to diversity cases so long as they are "arguably procedural,"223 that decision was grounded primarily on the Rules Enabling Act, ${ }^{224}$ which provides authority for creation of the federal rules but gives no guidelines for distinguishing between varying interpretations of them. Yet differing approaches to matters such as the requisites for certification of a class under Rule $23^{228}$ could have a significant effect on litigation, a reality reflected in the now-discredited "death knell" justification for immediate appealability of denials of class certification. ${ }^{226}$

221. 326 U.S. 99 (1945).

222. Of course, if one took an extreme acquired rights approach one would want to preserve transferor interpretation of the Federal Rules of Civil Procedure. To this extent, then, Van Dusen itself does not adhere to a strict acquired rights approach.

223. This is the way Justice Harlan described the rule of the majority opinion in Hanna. Hanna v. Plumer, 380 U.S. 460,476 (1965) (Harlan, J., concurring).

224. 28 U.S.C. $\$ 2072$ (1976).

225. Differences among the circuits on Rule 23 are certainly possible. For example, with regard to pre-certification decision of the merits, compare Katz v. Carte Blanche Corp., 496 F.2d 747 (3d Cir.) (en banc) (decision on liability before class certification permitted), cert. denied, 419 U.S. 885 (1974) with Peritz v. Liberty Loan Corp., 523 F.2d 349 (7th Cir. 1975) (certification of class after liability decision not permitted). With regard to the need to give pre-judgment notice in actions certified under Rule 23(b)(2), compare Larionoff v. United States, 533 F.2d 1167, 1186-87 (D.C. Cir. 1976) (need not give notice), aff'd, 431 U.S. 864 (1977) with Johnson v. General Motors Corp., 598 F.2d 432, 437 (5th Cir. 1979) (must give notice). For a recent Supreme Court decision resolving a conflict between the circuits on interpretation of Rule 23, see Crown, Cork \& Seal Co. v. Parker, 103 S. Ct. 2392 (1983).

Rule 23 is not the only rule that has received differing interpretations. For example, the availability of protective orders under Rule 26(c) has recently been the subject of much disagreement. See Marcus, Myth and Reality in Protective Order Litigation, 69 CORNenL L. REv. 1 (1983); see also Decker v. Massey-Ferguson Ltd., 29 Fed. R. Serv. 2d 239, 240 n.2 (S.D.N.Y. 1979), aff'd in part and rev'd in part, 681 F.2d 111 (2d Cir. 1982) (transferee circuit's interpretation of Fed. R. Civ. P. 9(b) should be applied).

226. The "death knell" doctrine treated a denial of class certification as immediately appealable on the ground that such litigation will not be pursued without class certification because the individual stake of each class member is too small. See Eisen v. Carlisle \& Jacquelin, 370 F.2d 119, 121 (2d Cir. 1966), cert. denied, 386 U.S. 1035 (1967). In Coopers \& Lybrand v. Livesay, 437 U.S. 463 (1978), the Court rejected this view of appellate jurisdiction, but it did not question the assumption that denial of certification would in fact sound the death knell of some class actions. See id. at 470 . The point here is only that the certification decision can have a significant impact on the outcome of a case. 
Nor is the problem limited to matters governed by the Federal Rules of Civil Procedure; differences of approach to other "procedural" issues could be extremely important. For example, consider the showing necessary to justify entry of an injunction. In a diversity case, federal law would govern this issue because the availability of equitable remedies in federal court for the violation of rights created by state law is properly a matter of federal law. ${ }^{227}$ But how does one resolve the problem if the transferee and transferor circuits themselves employ different standards for the issuance of an injunction? Moving even closer to substance, consider the popular doctrine of fraudulent concealment, used to toll the running of the statute of limitations where defendant has concealed his wrongdoing. In a diversity case, the availability of this doctrine is a matter governed by the applicable state law. ${ }^{228}$ There are substantial disparities between different circuits, however, about how the doctrine should be applied to federal claims. ${ }^{228}$ Should the transferor's approach be employed because it would be substantive for Erie purposes?

At present there is nothing to help the lower courts resolve these questions. The problems that they have encountered in answering analogous questions in diversity cases confirm the wisdom of interpreting the transfer statutes to avoid such confusion in federal claim cases by applying transferee law.

\section{c. Complications in Consolidated Cases.}

Consolidation of related cases is an important objective of both transfer statutes. The stated goal of multidistrict transfer is to allow coordinated or consolidated pretrial preparation. ${ }^{230}$ Similarly, under section 1404(a) the prospect of consolidation with litigation pending in the transferee court argues powerfully in favor of transfer. ${ }^{\mathbf{2 3 1}}$ This preference for combined treatment seeks to make the litigation more efficient and less burdensome

227. See Guaranty Trust Co. v. York, 326 U.S. 99, 106 (1945); 11 C. Wright \& A. MILleR, Federal Practice \& Procedure \$§ 2942-2943 (1973).

228. This conclusion follows from Guaranty Trust Co. v. York, 326 U.S. 99 (1945) and Holmberg v. Armbrecht, 327 U.S. 392 (1946). In the former, the Court held that the statute of limitations in a diversity case is governed by state law. In the latter, it held that where the claim is federally created, rules for tolling limitations due to concealment are federally determined. Clearly the tolling issues, like other limitations issues, are matters of state law in diversity cases. See Tracerlab, Inc. v. Industrial Nucleonics Corp., 313 F.2d 97 (1st Cir. 1963) (applying state tolling law to diversity claim).

229. I have discussed these differences between circuits at length in Marcus, Fraudulent Concealment in Federal Court: Toward a More Disparate Standard?, 71 Gro. L.J. 829 (1983). For an example of a court grappling with conflicting rules of fraudulent concealment in a transferred case, see Roth v. Bank of the Commonwealth, [1981-1982 Transfer Binder] FED. SEC. L. REP. (CCH) I] 98,267, at 91,712 (W.D.N.Y. Aug. 17, 1981).

230. See 28 U.S.C. $\$ 1407$ (a) (1976).

231. See cases cited in 15 Federal Practice \& Procedure, supra note 14, § 3854, at 281 n.5. 
for both the parties and the court. Requiring application of transferor law could frustrate these objectives.

Applying divergent legal standards may undermine consolidation. Consolidated cases can be handled effectively only if the same legal rules apply to them. ${ }^{232}$ Even such seemingly straightforward matters as the scope of discovery may depend upon the application of the legal rules that later will be used to decide the lawsuit. It was for precisely this reason that the proponents of the multidistrict transfer statute insisted that the transferee court have the power to resolve such issues going to the merits as part of its power to control discovery. ${ }^{233}$ Consolidation-and hence transfer-would be frustrated if such issues were resolved differently in different cases. Indeed, in Van Dusen itself the district court on remand decided against transfer because of the difference between the legal rules that would apply to the cases from Pennsylvania and those that would apply to the cases originally filed in Massachusetts. ${ }^{234}$ While such difficulties are justified in diversity cases by the principles on which Van Dusen is based, the same principles do not apply to transferred federal claim cases. Unless both transfer statutes are interpreted to apply the law of the transferee court, such disarray may eventually characterize all transferred cases.

The lower courts have not yet directly confronted the problem of interpreting the transfer statutes, ${ }^{235}$ but an indirect process leading to application of transferor law has occurred under the doctrine of the law of the case. Appropriately enough, it can be illustrated by the Plumbing Fixtures antitrust cases. ${ }^{236}$ In Plumbing Fixtures, the Judicial Panel on Multidistrict Litigation casually asserted that Van Dusen would apply to a transferred antitrust claim, thereby overcoming the objections of an indirect purchaser plaintiff that feared transfer to the Eastern District of Pennsylvania, which had already held that such plaintiffs lacked standing to sue. ${ }^{237}$ In Philadelphia, however, Judge Alexander Harvey was compelled by circumstance to take a different tack despite prior assurances of fealty

232. For a description of the difficulties caused by differing legal standards in diversity aircraft crash litigation, see Note, The Case For a Federal Common Law of Aircraft Disaster Litigation: $A$ Judicial Solution to a National Problem, 51 N.Y.U. L. REv. 231, 236-37, 257-60 (1976) (advocating creation of uniform federal law of air crashes).

233. Thus, Judge William Becker, testifying in support of the proposed multidistrict transfer statute, argued strongly in favor of giving transferee courts the power to decide legal issues. He asserted that "[i]t is impossible to separate discovery on factual issues from the power to make legal rulings" because the scope of discovery will often turn on such rulings. Hearings: Multidistrict Litigation Bill, supra note 200, at 21.

234. Popkin v. Eastern Air Lines, 253 F. Supp. 244, 249 (E.D. Pa. 1966).

235. But see In re Wickes Cos. Sec. Litig., [1982-1983 Transfer Binder] Fed. SEc. L. Rep. (CCH) II 99,085, at 95,179 (S.D. Cal. Jan. 25, 1983) (standards of secondary liability might be different for consolidated cases because they were transferred from various circuits).

236. In re Plumbing Fixtures Litig., 342 F. Supp. 756, 758 (J.P.M.D.L. 1972) (per curiam).

237. Id. at 758; see supra p. 712. 
to Van Dusen. ${ }^{238}$ Earlier in the consolidated proceedings, Judge Lord had granted defense motions to dismiss indirect purchaser plaintiffs in certain cases, ${ }^{239}$ presumably stimulating the unsuccessful effort to persuade the Panel not to transfer. Thereafter, similar defense motions were made in other cases, and the issue was argued by counsel on behalf of plaintiffs from the Fifth, Seventh, and Ninth Circuits who contended that indirect purchasers should have standing to sue. ${ }^{\mathbf{2 4 0}}$ Rather than reconsider the status of indirect purchasers, Judge Harvey let the earlier ruling stand as the law of the case, a principle he found "particularly applicable to multidistrict litigation in which the presence of a large number of diverse parties might otherwise result in constant relitigation of the same legal issues."241 It is not difficult to understand the practical necessity for Judge Harvey's ruling. There were 389 plumbing fixture cases pending before him $^{242}$ and undoubtedly he had enough problems resolving such issues once without confronting constant relitigation. While Judge Harvey's approach may raise legitimate considerations of due process, ${ }^{243}$ it hardly seems appropriate to interpret the transfer statutes as imposing on him the burden of relitigation.

Analogous administrative difficulties could frustrate the use of class actions. In both antitrust and securities litigation, plaintiffs have frequently used national or regional class actions, thereby relieving courts of duplica-

238. Judge Lord, Judge Harvey's predecessor in the case, had earlier supported a literal application of Van Dusen. In Philadelphia Hous. Auth. v. American Radiator \& Standard Sanitary Corp., 309 F. Supp. 1053 (E.D. Pa. 1969), he was presented with a venue challenge by a defendant in a case transferred from the District of Columbia pursuant to the multidistrict transfer statute. In deciding the motion, which required interpretation of the special venue provision of the Clayton Act, he held that Van Dusen required application of the District of Columbia interpretation of that venue statute and affirmed that "[t]he Court is mindful that District of Columbia law, and not Eastern District of Pennsylvania law, is to apply here." Id. at 1055.

239. Philadelphia Hous. Auth. v. American Radiator \& Standard Sanitary Corp., 50 F.R.D. 13 (E.D. Pa. 1970), aff'd sub nom. Mangana v. American Radiator \& Standard Sanitary Corp., 438 F.2d 1187 (3d Cir. 1971). The Supreme Court ultimately held, of course, that the district court was correct in holding that there was no standing to sue. See supra p. 688. Thus, compelling Judge Harvey to decide differently would have led to an incorrect result.

240. Philadelphia Hous. Auth. v. American Radiator \& Standard Sanitary Corp., 323 F. Supp. 381 (E.D. Pa. 1970).

241. Id. at 383. For other applications of the law of the case doctrine in transfer situations, see In re Exterior Siding \& Aluminum Coil Antitrust Litig., 696 F.2d 613 (8th Cir. 1982), cert. denied, 104 S. Ct. 204 (1983); Hayman Cash Register Co. v. Sarokin, 669 F.2d 162 (3d Cir. 1982); In re Upjohn Co. Antibiotic Cleocin Prods. Liab. Litig., 664 F.2d 114 (6th Cir. 1981).

242. Howard, A Guide to Multidistrict Litigation, 75 F.R.D. 577, 579 (1977).

243. Under Hansberry v. Lee, 311 U.S. 32 (1940), a nonparty may not be bound by a judgment against his "representative" unless adequate precautions are taken to protect his interests. In a sense, in a consolidated action like Plumbing Fixtures, binding the later plaintiffs or defendants to the results obtained by their fellows in earlier pretrial rulings involves appointing the litigants to the first decision as representatives of the others. For these reasons, in part, the Manual for Complex Litigation has an elaborate system for appointment of lead and liaison counsel to act on behalf of all. See MANuAl fOR COMPLEX LITIGation $\$ \S 1.90-.92$ (5th ed. 1982). Without some such protection of the rights of absent parties, there may be serious due process problems. 
tive individual actions and affording relief to large numbers of people. Often such litigations begin with class action complaints filed in a number of locations, which leads almost inevitably to an effort to transfer them all to one district. Indeed, the Panel has explicitly recognized the pendency of overlapping putative class actions as a factor strongly favoring transfer. ${ }^{\mathbf{2 4 4}}$

After transfer, additional problems arise. The transferee judge must decide whether to certify a class. That task is inherently difficult, but it becomes more so if the court must also consider the interpretations of the antitrust or securities law of the various transferor courts. Should the classes, if certified, be segmented by circuit? Does the law governing the rights of the class depend upon where the action was originally filed, with all the class members, wherever they reside, riding the choice-of-law coattails of the named representative?245 Among contending potential class representatives, is the choice-of-law issue relevant in selecting the class representative, giving the candidate who captured a favorable interpretation an edge? In diversity cases, the differences between legal standards can preclude the certification of a class consisting of residents of more than one state. ${ }^{246}$ It would be unfortunate to undermine Rule 23 in cases involving federal claims as well.

\section{Conclusion}

There has been no rush to determine whether Van Dusen should apply to transferred federal claims despite the large number of transfers. The

244. In re Piper Aircraft Distrib. Sys. Antitrust Litig., 405 F. Supp. 1402, 1403-04 (J.P.M.D.L. 1975). As of 1974 , it was reported that the Panel had transferred all cases involving potentially overlapping classes. Note, supra note 18, at 1010 \& n.41 (1974); see also Levy, supra note 20, at 51-52, 61-62 (1971).

245. It has been held that, in ruling on a motion of transfer under $\S 1404$ (a), the plaintiff's choice of forum is less important where the plaintiff represents a class than where he sues individually. See Blumenthal v. Management Assistance, Inc., 480 F. Supp. 470, 472 (N.D. Ill. 1979); Impervious Paint Indus. v. Ashland Oil, 444 F. Supp. 465, 467 (E.D. Pa. 1978). Contra Carty v. Health-Chem Corp., 36 Fed. R. Serv. 2d 122, 123-24 (E.D. Pa. 1982). Similarly, the Supreme Court has asserted that the plaintiff's forum selection in a derivative action is entitled to less weight: "[W]here there are hundreds of potential plaintiffs, all equally entitled voluntarily to invest themselves with the corporation's cause of action and all of whom could with equal show of right go into their many home courts, the claim of any one plaintiff that a forum is appropriate merely because it is his home forum is considerably weakened." Koster v. Lumbermens Mut. Casualty Co., 330 U.S. 518, 524 (1947) (footnote omitted).

246. See In re Northern Dist. of Cal., Dalkon Shield IUD Prods. Liab. Litig., 693 F.2d 847, 850 (9th $\mathrm{Cir}$. 1982) (overturning certification of nationwide class for punitive damages issues in part because of differences between state standards for awarding punitive damages), cert. denied, $103 \mathrm{~S}$. Ct. 817 (1983).

Much the same problem can arise in connection with the limitations period for a class that includes residents of several states asserting a federal claim in which there is no federal limitations period. The problem of "borrowing" a limitations period becomes difficult and may turn on the residence of class members, not the residence of the class representative. For an example of the difficulties this problem presents, see In re Clinton Oil Co. Sec. Litig., [1977-1978 Transfer Binder] FED. SEc. L. REP. (CCH) I 96,015, at 91,566-72 (D. Kan. Mar. 18, 1977). 
prospect of congressional action to revise the federal appellate structure may tempt the lower courts to continue to ignore this problem and simply to parrot Van Dusen without carefully considering its application. Whether or not Congress acts, however, problems from differing interpretations of federal law in transferred cases will not magically disappear. If Congress ever devises a solution to the problem of conflicts among the circuits, that development will provide yet another reason not to ask the transferee court to fathom and apply transferor law, since such a solution should rejuvenate a "national law" that is uniformly interpreted and make concerns about inconsistent decisions passé. Until that magic moment, however, the volume of transfers makes it important to decide the impact of differing interpretations on transferred cases.

Unfortunately, the Supreme Court is unlikely to provide guidance. Although individual Justices may assert that the Court is unable to resolve all significant conflicts, ${ }^{247}$ the Court cannot be expected to premise a decision on that inability. Moreover, in any case where the issue of choice between transferor and transferee interpretation might be presented, the Court would presumably decide the case on the merits rather than by promulgating rules regarding choice of interpretation. ${ }^{248}$ Like the possibility of congressional action, the prospect of Supreme Court guidance is not a reason for delay. The lower courts must therefore decide for themselves. They are of course quite willing to decide most issues for themselves, thereby creating conflicts among the circuits, but they have not come to grips with the problems that these conflicts raise in transferred cases.

This Article has attempted to unravel the issues that should bear on the handling of these conflicts in transferred federal claims cases. As it has shown, Van Dusen correctly controls transfers of diversity cases because permitting a change of law would jeopardize Erie concerns. ${ }^{249}$ But Erie is entirely irrelevant to transfers of federal claims. Acquired rights, the other ground for Van Dusen, provides no basis for deciding whether to apply the transferor's interpretation of federal issues. Accordingly, the reasoning of Van Dusen is inapplicable. In its place, this Article has proposed reliance on the principle that the transferee court is fully competent to decide issues of federal law. Requiring application of transferor interpretation would, by definition, offend this principle because it would only affect the

247. Sep supra note 1.

248. Thus, in Hoffman v. Blaski, 363 U.S. 335 (1960), discussed supra pp. 703-04, the Court, much to Justice Frankfurter's chagrin, gave no weight to the fact that the Seventh Circuit refused to accept the Fifth Circuit's earlier ruling in the same case as the law of the case. See supra note 163. Surely it would be less likely to address the consequences of a transfer on interpretation of federal law where the transferor circuit had not decided the actual case transferred.

249. See supra p. 695. 
outcome when the transferee court would reach a different result if free to decide the issues on the merits.

The ultimate question this Article addresses, therefore, is whether the transfer statutes justify thus offending the principle of competence. Legislative history provides little useful insight. One possible justification, a desire not to deter other transfers, is not persuasive. In general, the risk seems small. Under the multidistrict litigation statute, moreover, the Panel's emphasis on judicial efficiency greatly reduces the importance of possible prejudice to plaintiffs. Finally, there seems to be little reason to prefer the transferor interpretation simply to protect plaintiffs who forum shop for favorable interpretations; already some courts have transferred federal claims despite protests that the claim is viable only in the transferor circuit. ${ }^{230}$

The transfer provisions would, however, be impaired substantially by insisting upon adherence to transferor interpretation. Transferee judges would be burdened with the difficult task of divining the attitude of the transferor circuit; such adherence would present new problems in distinguishing between "substantive" matters, which are governed by transferor interpretation, and "procedural" matters, which are not; and consolidated treatment of transferred cases would become more difficult or perhaps impossible. In this day of escalating caseloads it is foolish to weaken the transfer devices, which attempt to utilize the unified federal judicial system to relieve part of the burden on the courts. The courts should therefore recognize that the transferee court must be free to decide a federal claim in the manner it views as correct without deferring to the interpretation of the transferor circuit.

250. See supra p. 706 (discussing Ackert v. Bryan, 299 F.2d 65 (2d. Cir. 1962)). 


\section{The Yale Law Journal}

Volume 93, Number 4, March 1984

\author{
John K. Setear \\ Editor-in-Chief \\ Thomas A. Smith \\ Note E Topics Editor \\ Kathryn R. Abrams \\ Dean M. Hashimoto \\ Daniel C. Richman \\ Stephanie I. Splane \\ Note Editors
}

C. Cabell Chinnis, Jr.
Managing Editor

Robert R. Harding

Pamela S. Karlan

Mercedes A. Laing

Eben Moglen

Stefan R. Underhill

Article \& Book Review Editors

\section{Senior Editors}

\author{
Eric O. Corngold \\ Stephen E. Creager \\ Michael R. Hepworth \\ Bruce D. Judson \\ Paul G. Mahoney
}

\author{
Stephen J. Massey \\ Michael B. Rappaport \\ Jefferey M. Sellers \\ Thomas R. Webb \\ Steven J. Weingarten
}

Editors

\author{
Akhil R. Amar \\ Steven A. Baronoff \\ Daniel M. Bodansky \\ Louis M. Bograd \\ Reuben C. Gahn \\ Vikram K. D. Chandhok \\ Brent M. Cohen \\ Lawrence P. Fletcher \\ Theresa Glennon
}

Daniel J. H. Greenwood

Michael O. Hill

Patricia A. Krieg

Myles H. Kuwahara

Debra L. Lagapa

Patrick A. Malone

Emily McKillip

Barbara E. Pace

Michael A. Paulsen

Anne Marie Pecht
Clifford L. Rechtschaffen

Michael H. Schill

Eileen F. Serene

Liang-Houh Shieh

Susan Lynn Stewart

Kent T. van den Berg

Henrietta Wright

Ronald F. Wright, Jr.

Rob G. Zeitinger

Business Manager: Pamela Standish Editorial Assistant: Claudia Shapiro

\section{Student Contributors to This Issue}

Kathryn Abrams, On Reading and Using the Tenth Amendment

Steven J. Weingarten, Tort Liability for Nonlibelous Negligent Statements: First Amendment Considerations 